\title{
GEOPHYSICAL LOGGING STUDIES IN THE SNAKE RIVER PLAIN AQUIFER AT THE IDAHO NATIONAL ENGINEERING LABORATORY- WELLS 44, 45, AND 46
}

\section{U.S. GEOLOGICAL SURVEY}

Water-Resources Investigations Report 92-4184
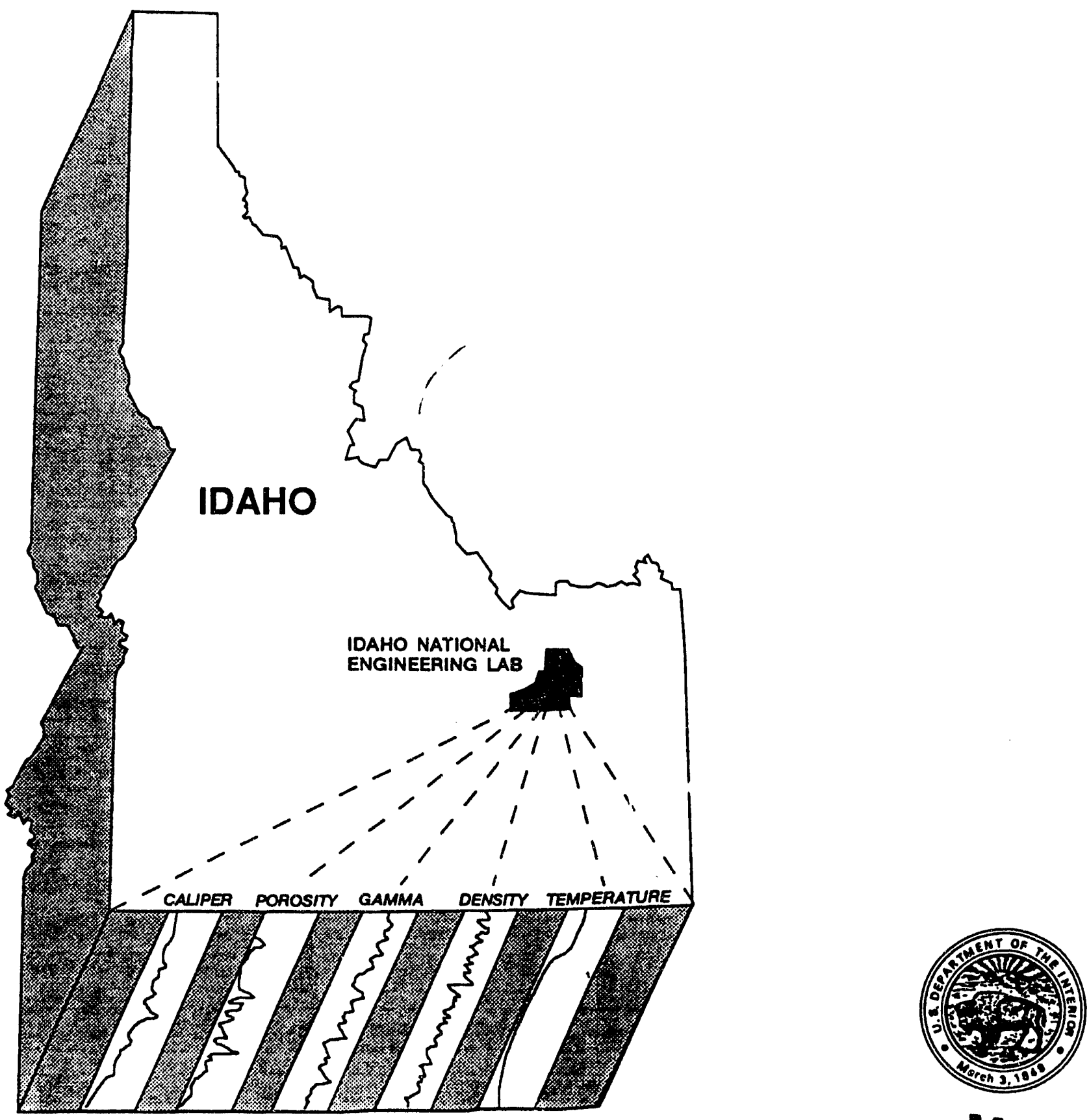


\section{GEOPHYSICAL LOGGING STUDIES IN THE SNAKE RIVER PLAIN}

\section{AQUIFER AT THE IDAHO NATIONAL ENGINEERING}

\section{LABORATORY-WELIS 44, 45, AND 46}

by R.H. Morin, U.S. Geological Survey,

Warren Barrash, Idaho Dept. of Health and Welfare, INEL Oversight Program,

F.L. Paillet, U.S. Geological Survey,

T.A. Taylor, U.S. Geological Survey

U.S. GEOLOGICAL SURVEY

Water-Resources Investigations Report 92-4184

FG07-91ID 13042

\section{DISCLAIMER}

This report was prepared as an account of work sponsored by an agency of the United States Government. Neither the United States Government nor any agency thereof, nor any of their employees, makes any warranty, express or implied, or assumes any legal liability or responsibility for the accuracy, completeness, or usefulness of any information, apparatus, product, or process disclosed, or represents that its use would not infringe privately owned rights. Reference herein to any specific commercial product, process, or service by trade name, trademark, manufacturer, or otherwise does not necessarily constitute or imply its endorsement, recommendation, or favoring by the United States Government or any agency thereof. The views and opinions of authors expressed herein do not necessarily state or reflect those of the United States Government or any agency thereof.

Denver, Colorado

1993

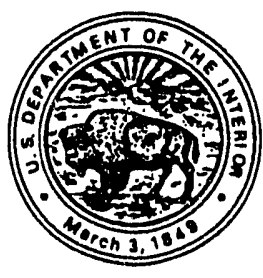




\section{U.S DEPARTHENT OF THE INTERIOR \\ BRUCE BABBITT, Secretary}

\section{U.S. GEOLOGICAL SURVEY}

Dallas L. Peck, Director

For additional information write to:

Chief, Branch of Regional Research U.S. Geological Survey Box 25046, Mail Stop 418 Federal Center Denver, C0 80225-0046
Copies of this report can

be purchased from:

U.S. Geological Survey Books and Open-File Reports Section Box 25425

Federal Center

Denver, C0 80225-0425 
TABLE OF CONTENTS

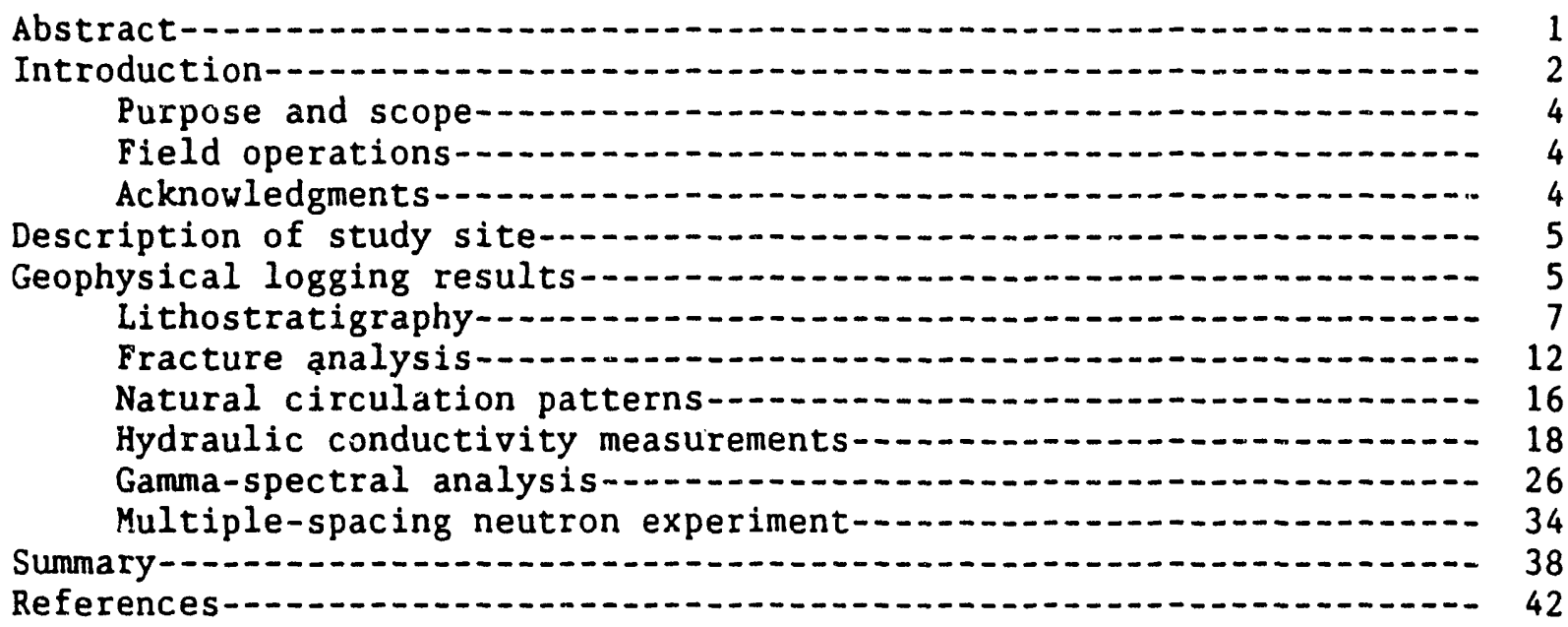

FIGURES

Figure 1. Geologic setting and selected facilities at the Idaho

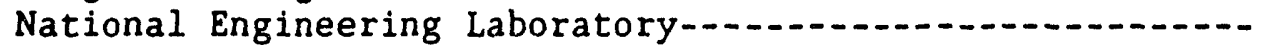

Figure 2. Location of wells 44,45 , and 46 among monitoring wells in the Snake River Plain aquifer near the Idaho Chemical Processing Plant (ICPP)

Figure 3. Composite of geophysical logs obtained from well $44 \ldots \ldots \ldots$ Figure 4. Composite of geophysical logs obtained from well 45-.....Figure 5. Composite of geophysical logs obtained from well 46-...-.-Figure 6. Plots showing (a) caliper log superimposed on the neutronporosity log for well 46 with both traces normalized to a common scale, and (b) corresponding residual between these two logs with locations of basalt flows identified graphically by a series of partial ellipses-...... 11

Figure 7. Diagram showing stratigraphic correlation among wells 44 , 45 , and 46 based on the neutron-porosity logs-........ 13

Figure 8. Sketches of borehole televiewer photos from wells 44, 45, and 46. Images are magnetically oriented and dark features represent areas of low acoustic reflectivity----- 14

Figure 9. Relations of (a) fracture strike azimuth to depth, and (b) fracture frequency to strike azimuth-............... 15

Figure 10. Sketches of natural fluid circulation patterns in wells 44,45 , and 46 based on thermal-flowmeter measurements and indicated by arrows-....

Figure 11. Horizontally layered hydraulic conductivity model (refer to equations 1 and 2 in text) aph showing vertical distribution of hydraulic conductivity in wells 44 and 45 . Values of hydraulic conductivity have an uncertainty of \pm 0.4 orders of magnitude-(- 
Figure 13. Diagram showing correlation of stratigraphy for wells 44 , 45, and 46 (from Anderson, 1991) with construction diagram of well CPP2 located near the Idaho Chemical Processing Plant-.......

Figure 14. Diagram showing characteristic gamma-energy signatures of the prominent, naturally occurring radionuclides uranium $(238 \mathrm{U})$, thorium $\left({ }^{232} \mathrm{Th}\right)$, and potassium $\left({ }^{40} \mathrm{~K}\right)$. Gamma energy scale is in million electron volts (MeV)

Figure 15. Energy spectrum showing characteristic energy peaks associated with several anthropogenic, $\gamma$-emitting isotopes barium $\left({ }^{133} \mathrm{Ba}\right)$, cesium $\left({ }^{137} \mathrm{Cs}\right)$, and cobalt $\left({ }^{60} \mathrm{Co}\right)-{ }_{0}-{ }_{0}$

Figure 16. Natural gamma logs obtained from wells 44,45 , and 46 . Open circles identify depths where gamma spectra were

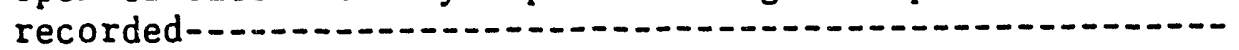

Figure 17. Graph showing energy spectrum (lower) obtained at a depth of 32 feet in well 45 compared to the point-source calibration spectrum (upper). Symbols are defined in figures 14 and 15

Figure 18. Graph showing residual energy spectrum produced by subtracting background reference spectrum from low ar spectrum shown in figure 17-

Figure 19. Schematic illustration of neutron cloud generated by neutron source in a conventional logging probe-.....-.-

Figure 20. Graph showing neutron counts measured at six different source-recelver spacings in well 45 over a depth interval where count readings are nearly constant. Curve represents the neutron counts predicted by far-field scattering theory (refer to equation 3 in text)

Figure 21. Comparison of neutron logs obtained at six different source-receiver spacings in well 45 for the depth interval 180-380 feet below land surface with the natural gamma log for the same interval--

TABLES

Table 1. Thermal-flowmeter measurements in wells 44,45 , and $46--\ldots--17$

Table 2. General information on in-situ gamma spectra obtained from wells 44, 45, and 46- 30

Table 3. Neutron source-receiver spacing (inches) in the dual-detector, variable spacing experiment- 36 
CONVERSION FACTORS, ABBREVIATED UNITS AND TERMS, AND VERTICAL DATUM

Multiply

gallon

gallon per minute (gal/min)

foot (ft)

inch (in)

mile (mi)

square miles $\left(\mathrm{mi}^{2}\right)$

To convert degrees Fahrenheit $\left({ }^{\circ} \mathrm{F}\right)$ to degrees Celsius $\left({ }^{\circ} \mathrm{C}\right)$, use the following formula:
By

3.785

0.06309

0.3048

25.40

1.609

2.589
To obtain

liter

liter per second

meter

millimeter

kilometer

square kilometers

The following terms and abbreviations also are used in this report:

feet below land surface ( $\mathrm{ft}$ bls)

feet above mean sea level ( $\mathrm{ft}$ amsl)

feet per day $(\mathrm{ft} / \mathrm{d})$

foot per minute ( $\mathrm{ft} / \mathrm{min})$
gram per cubic centimeter $\left(\mathrm{g} / \mathrm{c}^{3}\right)$

million electron volts ( $\mathrm{MeV}$ )

counts per second (cps)

National Geodetic Vertical Datum of 1929 (NGVD of 1929): A geodetic datum derived from a general adjustment of the first-order level nets of both the United States and Canada, formerly called "Mean Sea Level." NGVD of 1929 is referred to as mean sea level in this report. 


\title{
GEOPHYSICAL LOGGING STUDIES IN THE SNAKE RIVER PLAIN AQUIFER AT THE
}

\author{
IDAHO NATIONAL ENGINEERING LABORATORY--WELLS 44, 45, AND 46
}

R.H. Morin, Warren Barrash, F.L. Paillet, and T.A. Taylor

\begin{abstract}
A geophysical logging program was undertaken to vertically profile changes in the hydrology and hydrochemistry of the Snake River Plain aquifer that underlies the Idaho National Engineering Laboratory (INEL). Field investigations were concentrated within an area west of the Idaho Chemical Processing Plant (ICPP) in three wells that penetrated the upper 190 feet of the aquifer. The logs obtained in these wells consisted of temperature, caliper, nuclear (neutron porosity and gamma-gamma density), natural gamma, borehole televiewer, gamma spectral, and thermal flowmeter (with and without pumping).

The nuclear, caliper, and televiewer logs are used to delineate individual basalt flows or flow units and to recognize breaks between flows or flow units at interflow contact zones and sedimentary interbeds. The temperature logs and flowmeter measurements obtained under ambient hydraulic head conditions identified upward fluid-circulation patterns in the three wells. Reversal of in-hole fluid-flow direction indicated hydraulic communication between well 46 and the supply well CPP2 at the ICPP. The vertical distributions of hydraulic conductivity in wells 44 and 45 were determined by measuring fluid flow in the wells concurrently with pumping. The large variations in the vertical distributions and magnitudes of hydraulic conductivity determined from these field tests testify to the complex, heterogeneous nature of the hydrogeologic system at the ICPP.
\end{abstract}

Gamma-spectral analyses performed at several depths in each well showed that the predominant source of gamma radiation in the formation at this site originates mainly from potassium $\left({ }^{40} \mathrm{~K}\right)$. However, the anthropogenic, $\gamma$-emitting isotope ${ }^{137}$ Cesium was detected at 32 feet below land surface in well 45 .

An empirical investigation of the effect of source-receiver spacing on the response of the neutron-porosity logging tool was attempted in an effort to understand the conditions under which this tool might be applied to large-diameter boreholes in unsaturated formations. Results indicate that large spacings of $4 \mathrm{ft}$ or more are required in order to effectively use the conventional porosity calibration approach for this purpose. 


\section{INTRODUCTION}

The Idaho National Engineering Laboratory (INEL) is situated on about $890 \mathrm{mi}^{2}$ of the eastern Snake River Plain in southeastern Idaho (fig. 1). INEL facilities and resources are employed in the development of nuclear safety research and advanced energy concepts. The Snake River Plain aquifer serves as the source of water for a variety of functions at the INEL; liquid wastes generated at this facility have been discharged to onsite infiltration ponds and disposal wells drilled into this aquifer since 1952.

One of the most important concerns in heterogeneous aquifers such as the one underlying the INEL is the potential for rapid dispersal of contaminants along conduits provided by rubble zones or open fractures in otherwise dense and relatively impermeable basalt flows. Geophysical measurements in boreholes, such as caliper and acoustic televiewer logs, provide information about the physical properties of these rocks.

Identification of high-permeability rubble zones and fractures, coupled with complementary borehole flow measurements, represents a powerful method for characterizing the flow paths and interconnections that control the movement of solutes in the aquifer. This information is particularly useful in assessing the performance of contaminant-dispersal models and in specifying the parameters to be used in the formulation of improved models.

As part of an ongoing multidisciplinary effort by the U.S. Geological Survey (USGS) to characterize the hydrogeological regime underlying the INEL, borehole geophysical techniques were used to supplement and extend the hydrologic data base for this area. A geophysical logging program was undertaken by the USGS and the State of Idaho INEL Oversight Program to vertically profile changes in the hydrology and hydrochemistry of the aquifer. A preliminary well-logging survey conducted in 1990 was designed to assess the performance and applicability of a variety of downhole instruments and to identify the general geophysical properties of sediments and basalt flows underlying the site. This survey demonstrated the range of responses obtained with conventional electric and nuclear logs and indicated specific measurements that might be useful in characterizing local hydraulic properties.

The results of the preliminary field work indicated several approaches that might be especially effective in characterizing the potential for contaminant dispersal at the INEL. One of these, neutron-porosity logging, appeared to have applications in the unsaturated zone. Another approach, permeability profiling with a high-resolution flowmeter, showed promise in identifying flow regimes in the aquifer. A third method, gamma-spectral logging, appeared to be useful in the interpretation of ion-exchange capacity of clay minerals in the unsaturated and saturated zones and in detecting the presence of anthropogenic radionuclides. Based on this preliminary information, a testing strategy was formulated and a comprehensive set of downhole measurements was performed during fall 1991 in three wells that penetrated the upper 190 feet of the Snake River Plain aquifer. This report presents the results of these geophysical logging activities. 


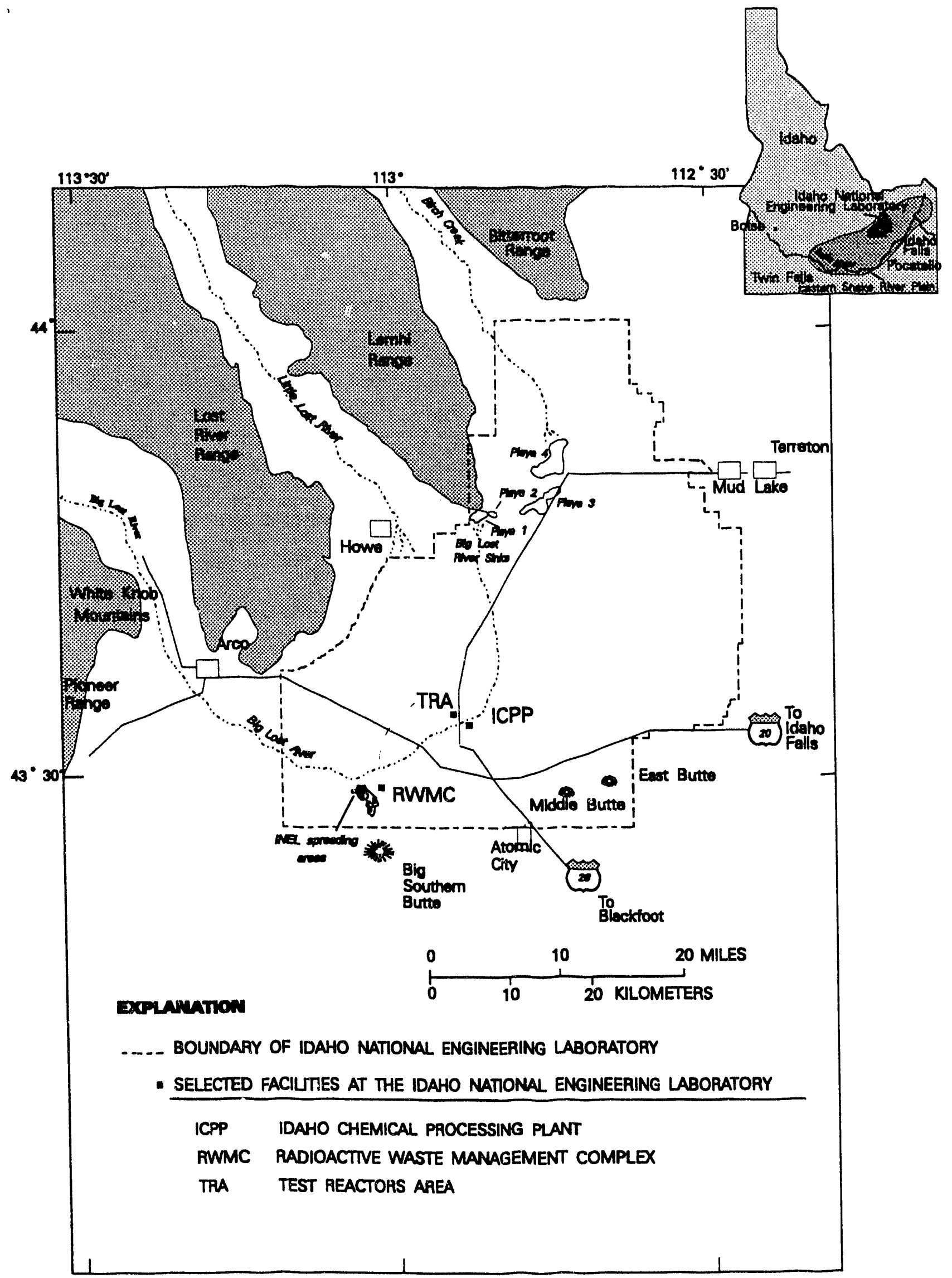

Figure 1. Geologic setting and selected facilities at the Idaho National Engineering Laboratory. 


\section{Purpose and Scope}

This report presents the results of geophysical logging activities at three wells located near the ICPP. The data are intended to characterize in detail a small part of the Snake River Plain aquifer that underlies the INEL and to contribute to the general understanding of the regional hydrologic system. Geophysical logs are presented that provide lithostratigraphic information that can be correlated spatially. Acoustic images of the borehole walls describe local fractures penetrated by the wells and flowmeter measurements identify the subset of these fractures that control fluid flow. This report is intended to complement the numerous and diverse geologic investigations relavent to the INEL and to illustrate the potential usefulness of geophysical logs when applied to hydrologic studies.

\section{Field Operations}

A comprehensive series of downhole measurements was conducted in three wells that are only a few hundred feet apart and that were drilled using the cable-tool method by the same driller in 1957-58 (U.S. Department of Energy, 1990). Total depth of each well is approximately $650 \mathrm{ft} ; 6.25$-inch-diameter casing extends to the water table. Depth to water is about $460 \mathrm{ft}$ below land surface (bls) or about 4,460 ft in elevation above mean sea level (amsl). Measurements related to borehole gamma-spectral analyses and a variable-spacer, neutron-porosity experiment were obtained throughout the well; the other geophysical logs were limited to the saturated part of the holes extending from botton of casing to total depth. Thus, data collected as part of this logging study are primarily from the upper $190 \mathrm{ft}$ of the Snake River Plain aquifer.

The standard suite of logs run in the wells included temperature, caliper, natural gamma, and nuclear logs. The nuclear logs, those obtained from a logging probe housing a nuclear source, consisted of neutron porosity and gamma-gamma density. Log responses were recorded and digitized at $0.1-\mathrm{ft}$ intervals. A detailed discussion of these types of logs, their particular sampling volumes, and their principles of operation is presented by Keys (1990). These standard logs were supplemented by two specialty tools: (1) the borehole televiewer, which produces a magnetically oriented acoustic image of the borehole wall (Zemanek and others, 1970), and (2) the thermal flowmeter, which measures vertical fluid flow rates as slow as 0.05 $\mathrm{gal} / \mathrm{min}$ (Hess, 1986). The flowmeter was used before and during pumping to identify natural circulation patterns and to profile vertical changes in hydraulic conductivity in the borehole.

\section{Acknowledgments}

The authors wish to express their appreciation to S.R. Anderson, D.J. Ackerman, and S.H. Wood for thorough and deliberate reviews that greatly improved the first draft of this report. Thanks are also extended to James Olsen and Flint Hall, State of Idaho INEL Oversight Program, for their logistical help at the field site. 


\section{DESCRIPTION OF STUDY SITE}

The three wells selected for this borehole-geophysics study were located a few hundred feet to the west of the Idaho Chemical Processing Plant (ICPP): wells 44, 45, and 46 (fig. 2). The ICPP, located about $8 \mathrm{mi}$ north of the southern boundary of the INEL (fig. 1), is used for the reprocessing of spent nuclear fuel rods. Associated radioactive and chemical wastes have been discharged to disposal wells and unlined percolation ponds at this facility for several decades (Pittman and others, 1988).

The area is underlain by the Snake River Plain aquifer, which consists of a complex stratified series of basalt flows separated in places by sedimentary interbeds (Garabedian, 1989). On the basis of paleomagnetic data, K-Ar ages, and natural gamma logs, Anderson (1991) identified 23 basalt flow groups, 40 basalt flows, and 15-20 sedimentary interbeds in the unsaturated zone and uppermost part of the aquifer to a depth of 700 feet at the ICPP. Individual lava flows are generally about 20-25 ft thick and cover most of the study area.

Core and log data retrieved from wells throughout the INEL indicate that the centers of basalt flows consist of massive, competent rock commonly bounded above and below by rubble zones and sedimentary interbeds. It is these porous, rubbly interflow zones that are thought to account for the substantial transmissivity in parts of the Snake River Plain aquifer (Ackerman, 1991). Regional ground-water movement is generally southwesterly at velocities estimated to be: between 5 to $20 \mathrm{ft} / \mathrm{d}$ (Robertson and others, 1974; Barraclough and others, 1979) and aquifer discharge occurs primarily at the Thousand Springs area near Hagerman, Idaho, about $100 \mathrm{mi}$ southwest of the INEL.

\section{GEOPHYSICAL LOGGING RESULTS}

The comprehensive set of geophysical logs obtained during this field study may be divided into two principal categories. In the first category are those logs that provide information about the surrounding rock; these include the nuclear logs, the caliper log, and the borehole televiewer log. The second category includes logs that measure various properties of the borehole fluid rather than the surrounding formation; these are the temperature $\log$ and flow measurements. Data from both categories typically are interrelated and complementary; for example, flow patterns in a well may be linked to discrete lithologic contacts or fractures having a particular orientation. The systematic inspection of all logs can yield fundamental information regarding the hydrogeologic structure of an aquifer. 


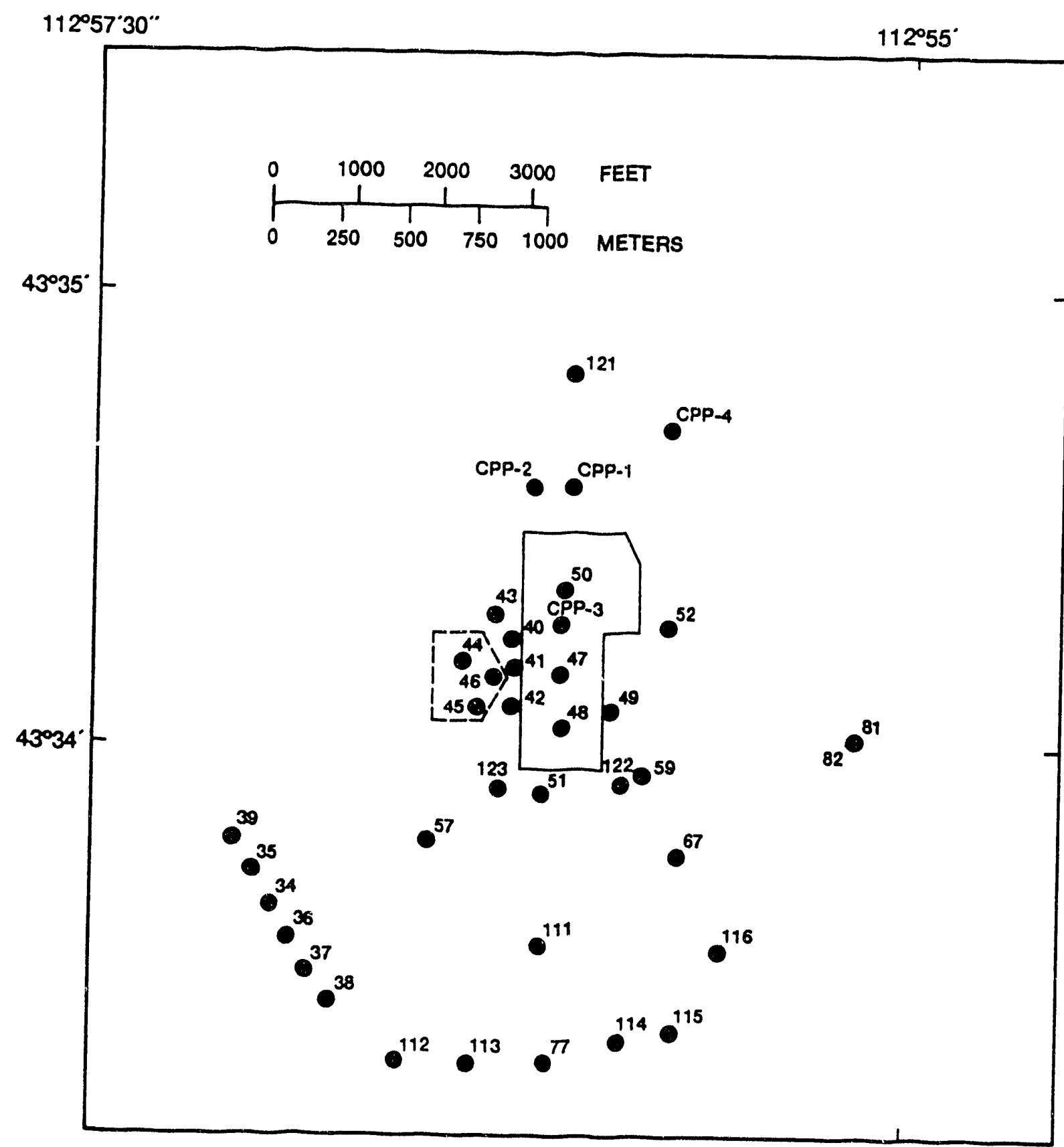

Figure 2. Location of wells 44,45 , and 46 among monitoring wells in the Snake River Plain aquifer near the Idaho Chemical Processing Plant (ICPP). 


\section{Lithostratigraphy}

The geophysical logs whose responses are directly affected by the physical properties of the surrounding formation are now examined. Log composites generated from this investigation are presented in figures 3, 4, and 5 for wells 44,45 , and 46 , respectively. Inspection of these traces indicates a relation between the nuclear logs and formation lithostratigraphy that is clearly distinguishable in wells 45 and 46 , but less obvious in well 44. An alternating pattern of high-low-high porosity and, conversely, of low-high-low density appearing as a function of depth delineates individual basalt flows (Anderson, 1991). Basalt flows are characterized by dense, low-porosity centers. The flow centers have relatively few fractures, as interpreted from the televiewer log. These units also are bounded by high-porosity, rubbly interflow zones.

A sharp stratigraphic marker commo: to all wells is the high-porosity spike at a depth of approximately $540 \mathrm{ft}$. This is identified by Anderson (1991) as sediment/rubbie just above flow group I. Geologic sections near the ICPP described by Anderson (1991) show only a few thin sedimentary interbed deposits below the water table. Complementary descriptions of cuttings from wells 44,45 , and 46 also present little evidence of sediment. This observation is supported by the neutron and gamma-gamma logs and by the televiewer images, which suggest that the high-porosity/low-density spikes represent fractured, rubbly flow contacts rather than porous sands and clays. In addition, spikes in the natural-gamma logs that are characteristic of sedimentary interbeds are not evident in these wells.

Inspection of the caliper logs from wells 44,45 , and 46 shows a clear correlation between hole diameter and formation porosity and density (figs. 3,4 , and 5); borehole enlargements tend to coincide with high-porosity/lowdensity intervals. This apparent correlation introduces some question as to whether the nuclear log responses are a genuine reflection of formation properties or whether they are primarily an artifact of changes in borehole diameter. If they are mainly an indication of borehole diameter, their usefulness as a tool for stratigraphic interpretation is limited.

In order to properly evaluate the apparent correlation between the caliper and nuclear logs, the caliper and neutron-porosity logs from well 46 were normalized and superimposed on each other to compare each profile at a common scale. Several examples of this graphical overlay method for the analysis of log data are described by Paillet (1991). The normalized caliper log was then subtracted from the normalized neutron-porosity $\log$ and the residual is illustrated in figure 6 . This exercise filters the effects of a variable wellbore geometry from the log trace. The resulting profile retains to a certain degree the characteristic pattern delineating basalt flows as outlined by the partial ellipses superimposed on the plot for emphasis. However, the familiar pattern is less distinctive in this plot than in the individual caliper or neutron-porosity logs. Thus, it appears that the nuclear logs do respond to the physical properties of the surrounding rock, but that the data are not completely independent of borehole-enlargement effects, particularly when the diameter exceeds 15 inches. This observation also implies that the correlation between the caliper and nuclear logs is related to formation properties. Accordingly, the caliper log provides additional stratigraphic information, becoming 

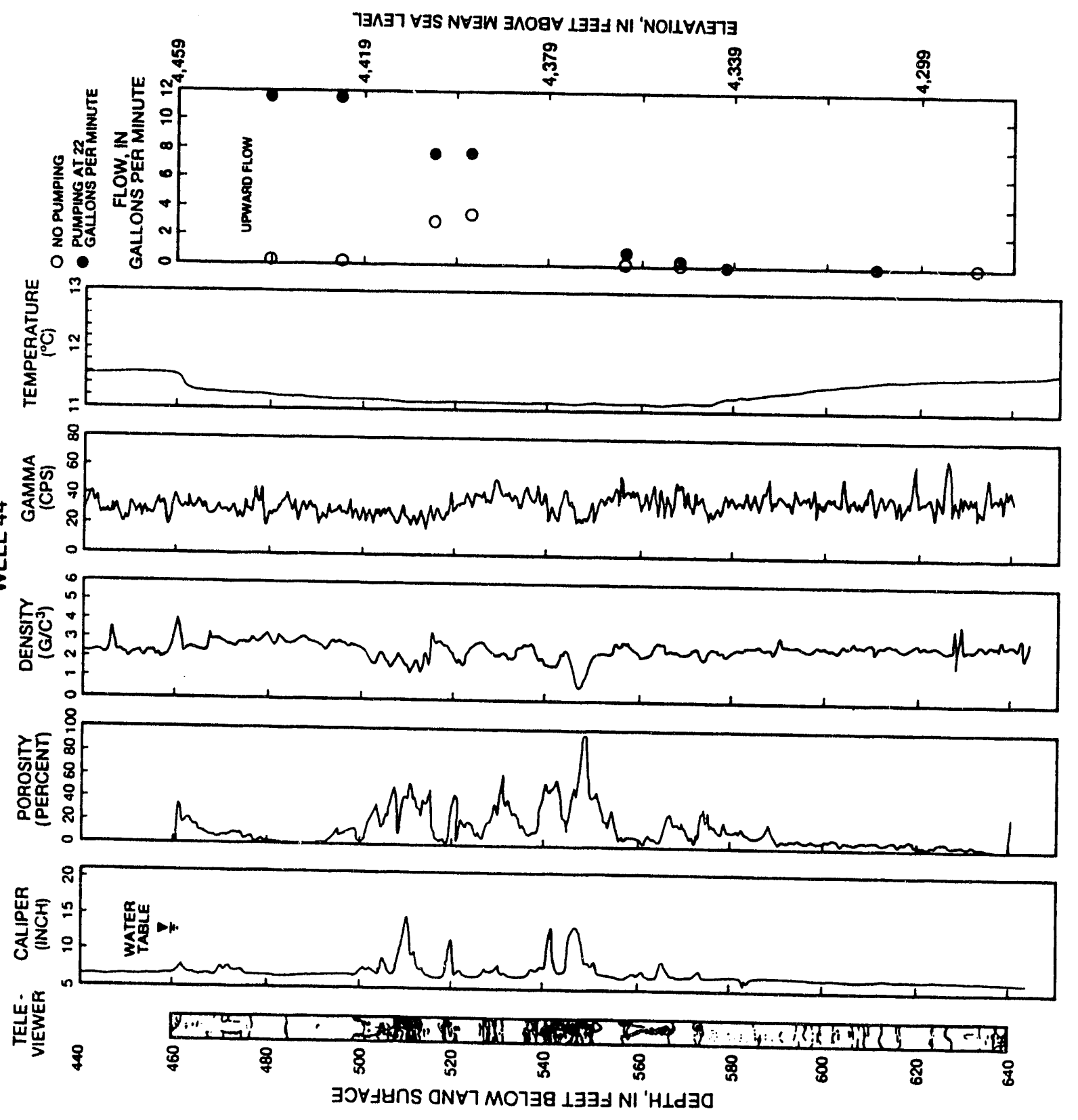


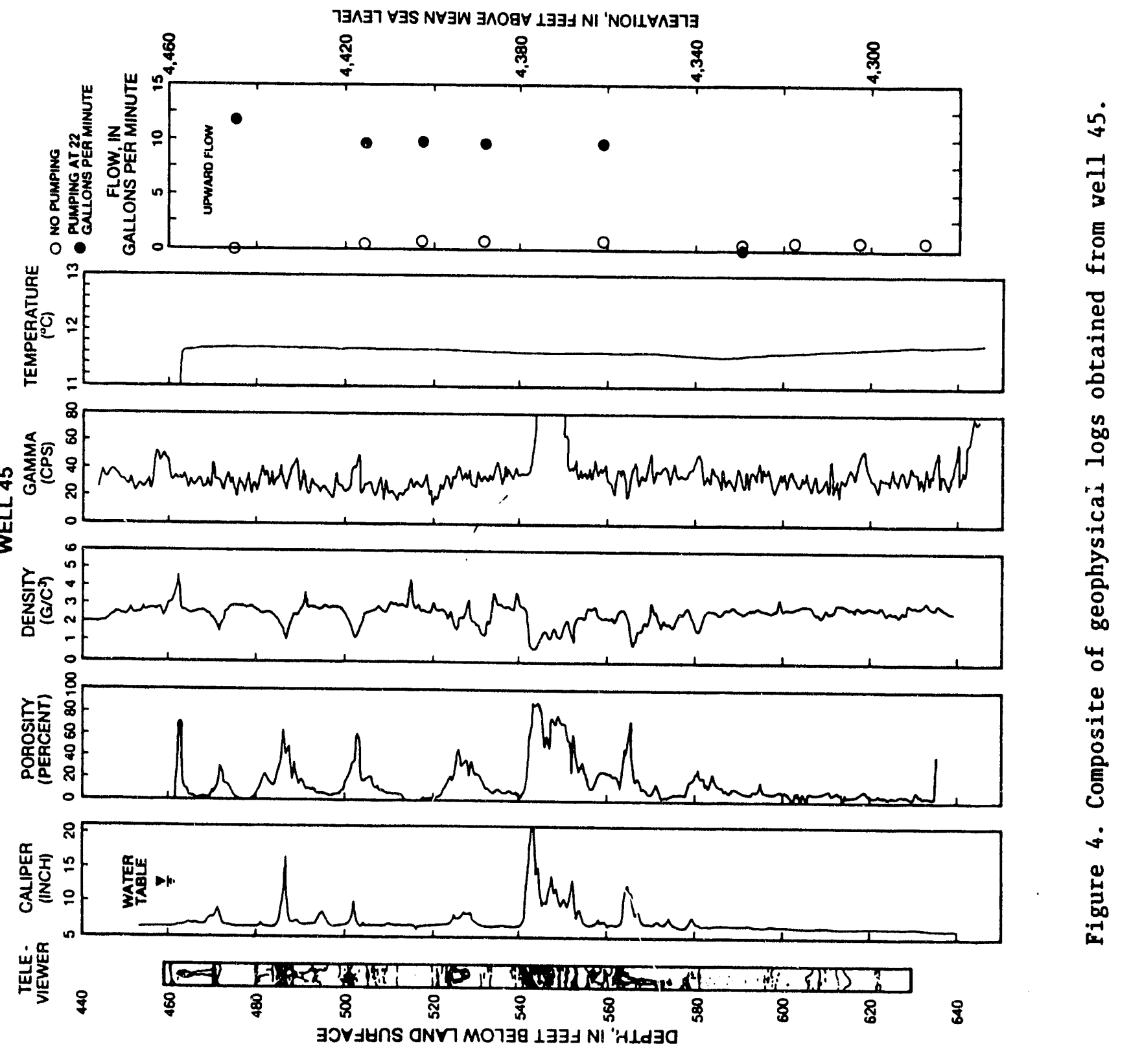




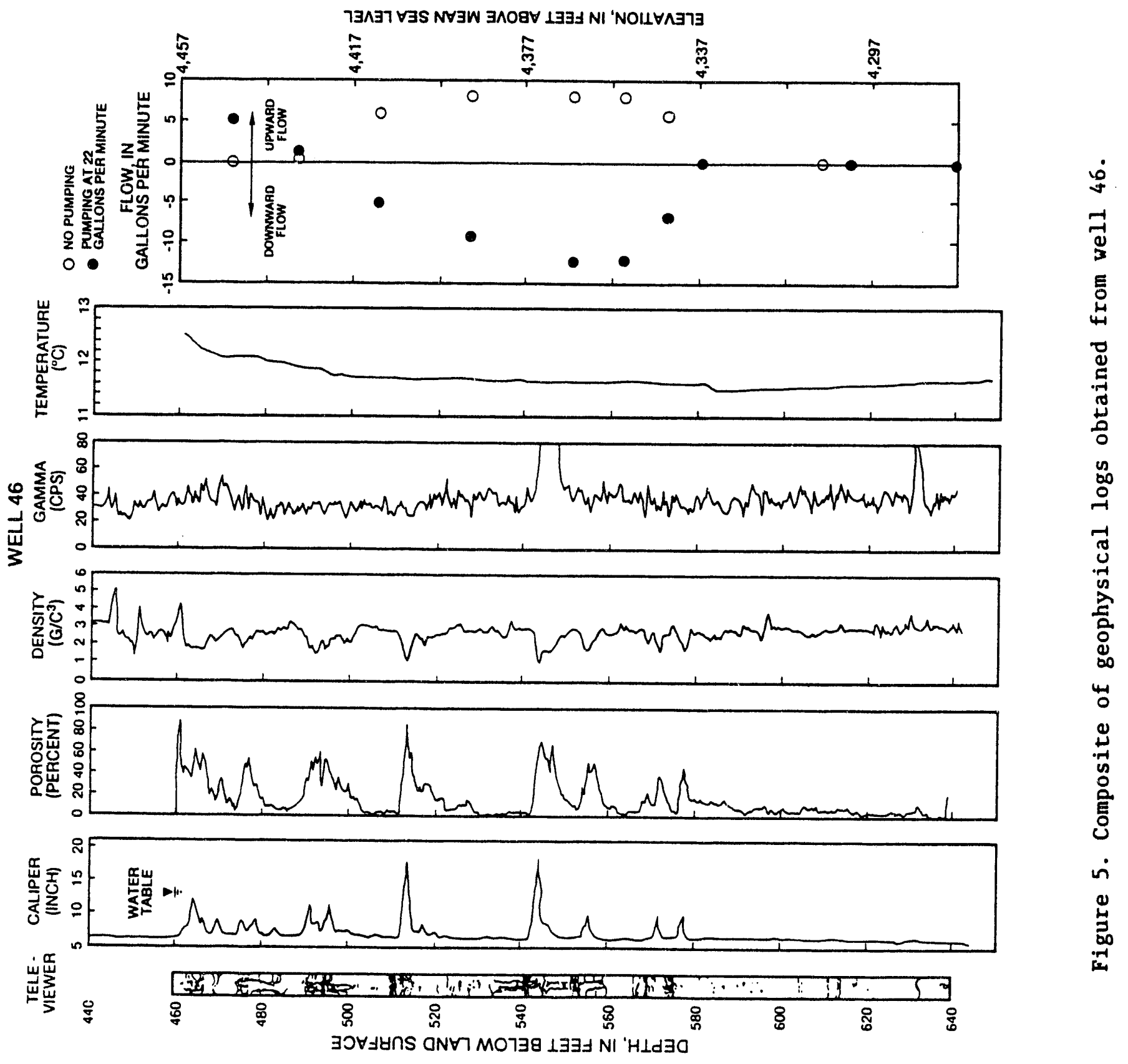


WELL 46
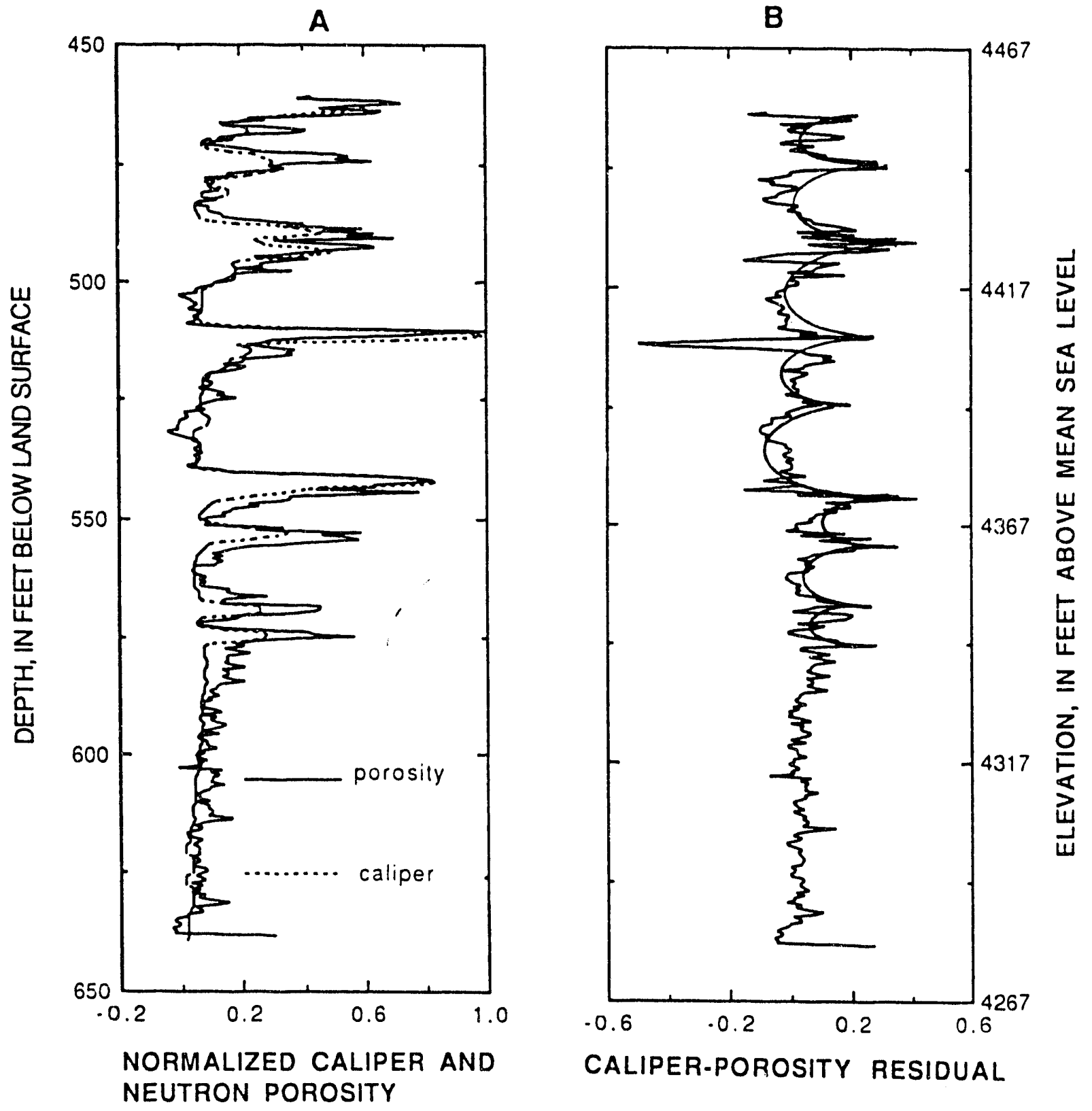

Figure 6. Plots showing (a) caliper log superimposed on the neutronporosity log for well 46 with both traces normalized to a common scale, and (b) corresponding residual between these two logs with locations of basalt flows identified graphically by a series of partial ellipses. 
larger at interflow contacts where the surrounding rock is rubbly, fractured, and weak, and remaining close to gage (diameter of the drillbit) where the rock is dense and competent. This type of correlation between borehole size and physical properties has been recognized by Jones (1961) at this site and by Morin and others (1992) in an oceanic borehole penetrating a similar lithologic sequence.

The neutron-porosity, density, caliper, and televiewer logs all provide supporting stratigraphic control and are used to identify flows in the upper $190 \mathrm{ft}$ of the aquifer. Of these four logs, the neutron-porosity log exhibits the clearest stratigraphic signature. Eight separate flows can be identified in wells 44 to 46 to 45 (fig. 7) along roughly a north-south transect (fig. 2). Below a depth of approximately $580 \mathrm{ft}$, the periodic porosity spikes disappear, the caliper log stabilizes close to drillbit gage, and the televiewer images depict a grainy interval about $15-25 \mathrm{ft}$ thick. This type of grainy texture shown on the televiewer log typically is representative of vesicular basalt (Paillet and Kim, 1987). Below $580 \mathrm{ft}$, rubbly zones and fractures are less common and the porosity and density remain relatively uniform, with no further contact boundaries indicated to total depth of the wells.

\section{Fracture Analysis}

The televiewer generates acoustic images of the borehole wall and allows for the visual inspection of fractures intersecting the wellbore (Zemanek and others, 1970). Because the images are magnetically oriented, fractures can be characterized not only in terms of size, frequency, and vertical distribution but in terms of fracture strike and dip as well. The televiewer logs from wells 44,45 , and 46 ( $\mathrm{fig} .8$ ) were inspected for fracture information, and a total of 34 discrete fractures were identified. These were not associated with rubbly, brecciated zones where wellbore damage was extensive and individual fractures could not be distinguished. Rather, these were separate, distinctive features recognizable in the televiewer photographs. Dip angles and azimuths were measured directly from these photos, and azimuthal values were adjusted for the local magnetic declination in southeastern Idaho.

Dip angles vary over a wide range, from steeply dipping features that extend vertically for 10-15 ft to subhorizontal depositional contacts. The strike azimuths of dipping fractures are plotted in figure $9 \mathrm{a}$ as a function of elevation. This plot summarizes the data from all three wells, with no obvious pattern of fracture distribution versus depth. This heterogeneity in fracture dip and distribution is consistent with volcanic rock such as basalt, where most fractures are cooling joints unrelated to local tectonic stresses. A complementary histogram of strike azimuths (fig. 9b), which demonstrates a wide variation in directions of strike, also defines a primary mode for this fracture population with a median orientation of $\mathrm{N}$. $30^{\circ}$ E. Although a preferential fracture orientation striking northeast-southwest is recognized from the televiewer data, these results are based on a small sample size, are limited spatially to three closely spaced wells, and have little surface expression in terms of tectonic structure in the Snake River Plain. 


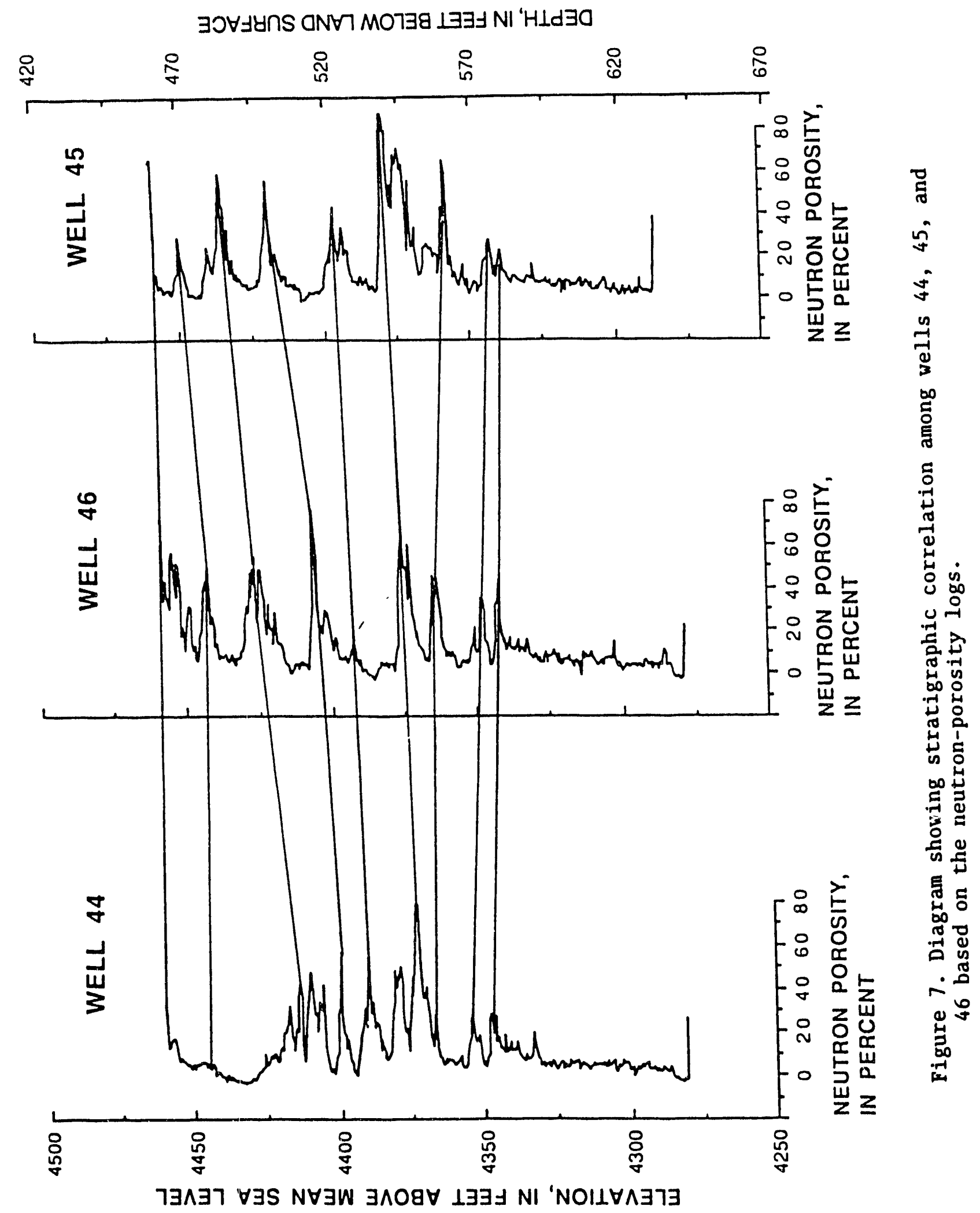




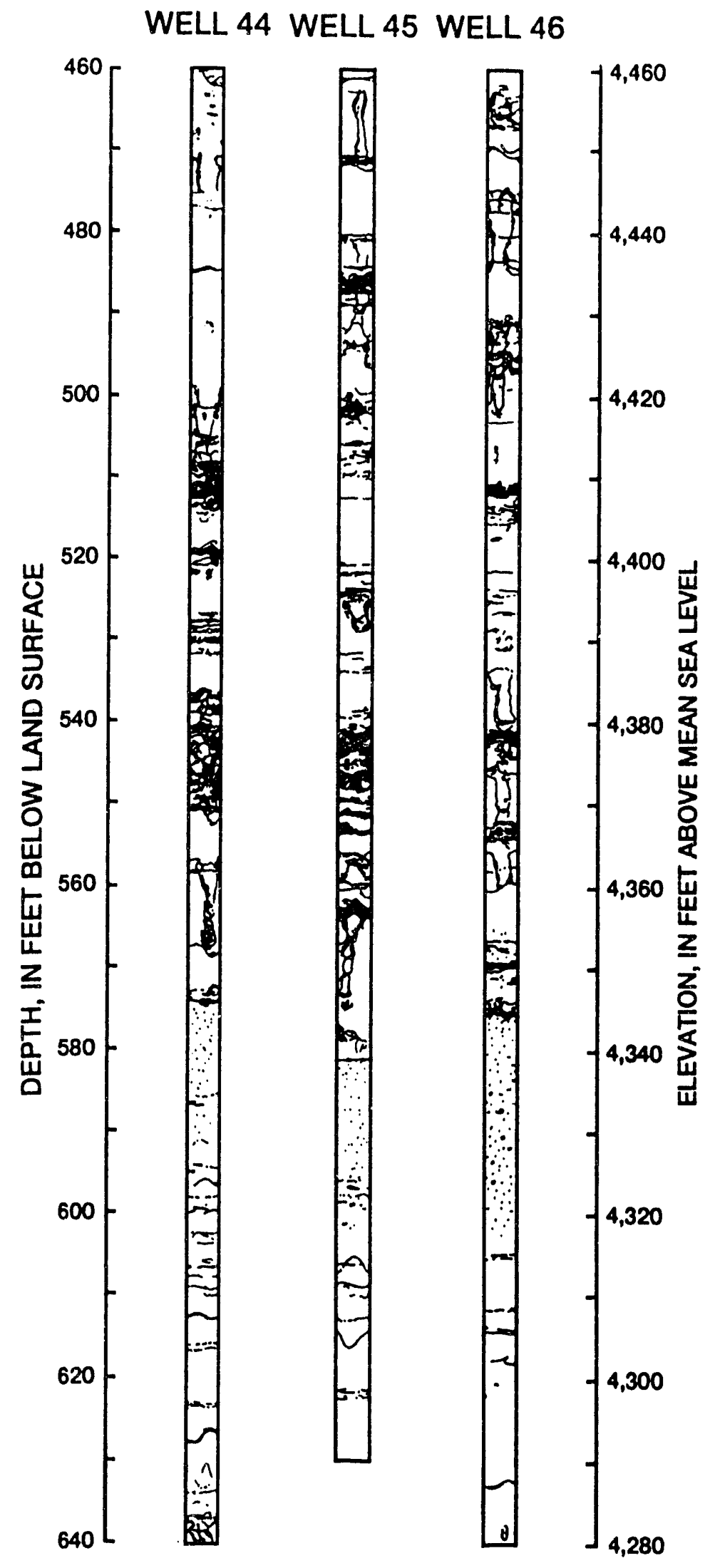

Figure 8. Sketches of borehole televiewer photos from wells 44, 45, and 46 . Images are magnetically oriented and dark features represent areas of low acoustic reflectivity. 


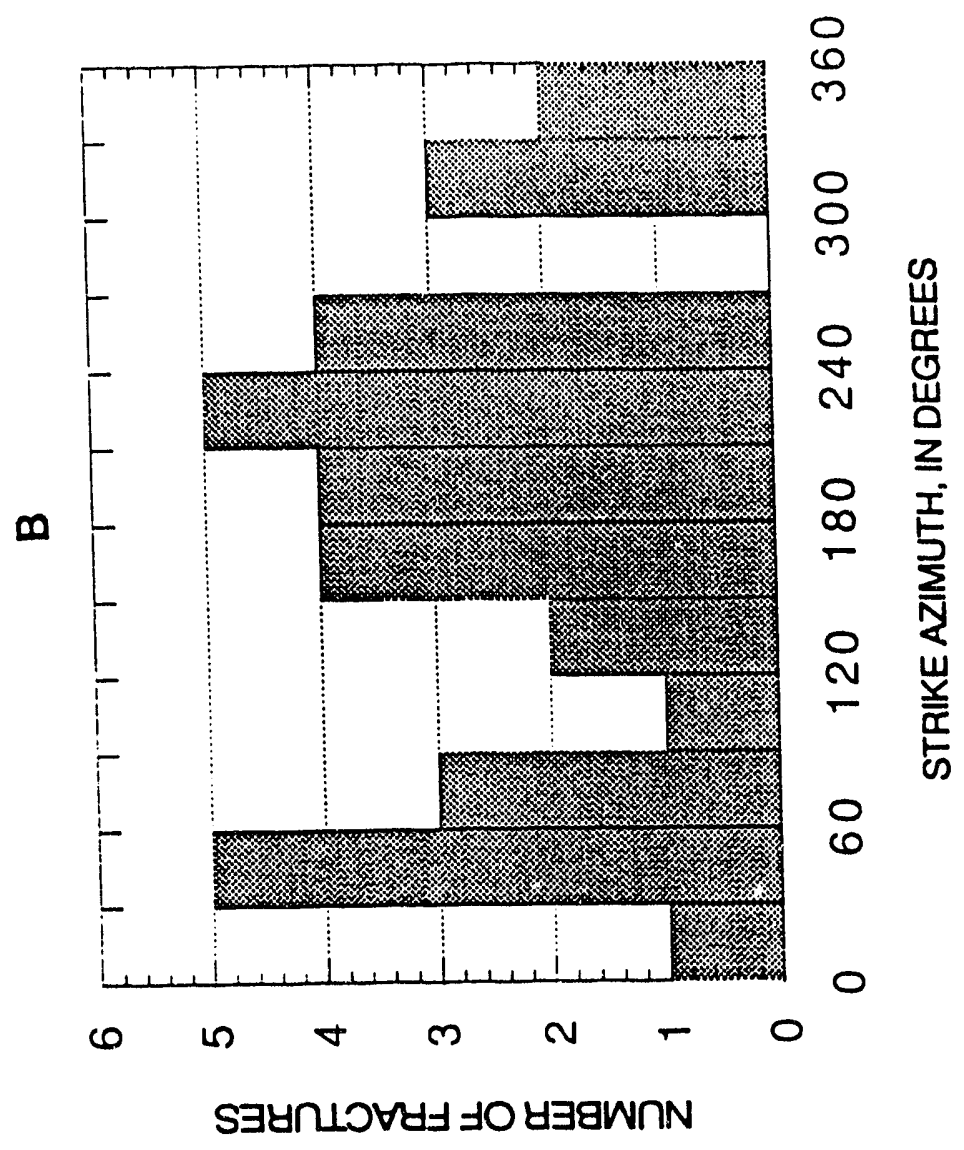

룽

용

운

焉焉

온

눈

i

43

T)

4.

(

ธํㅇ

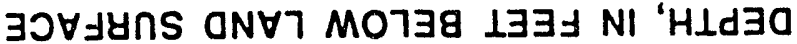

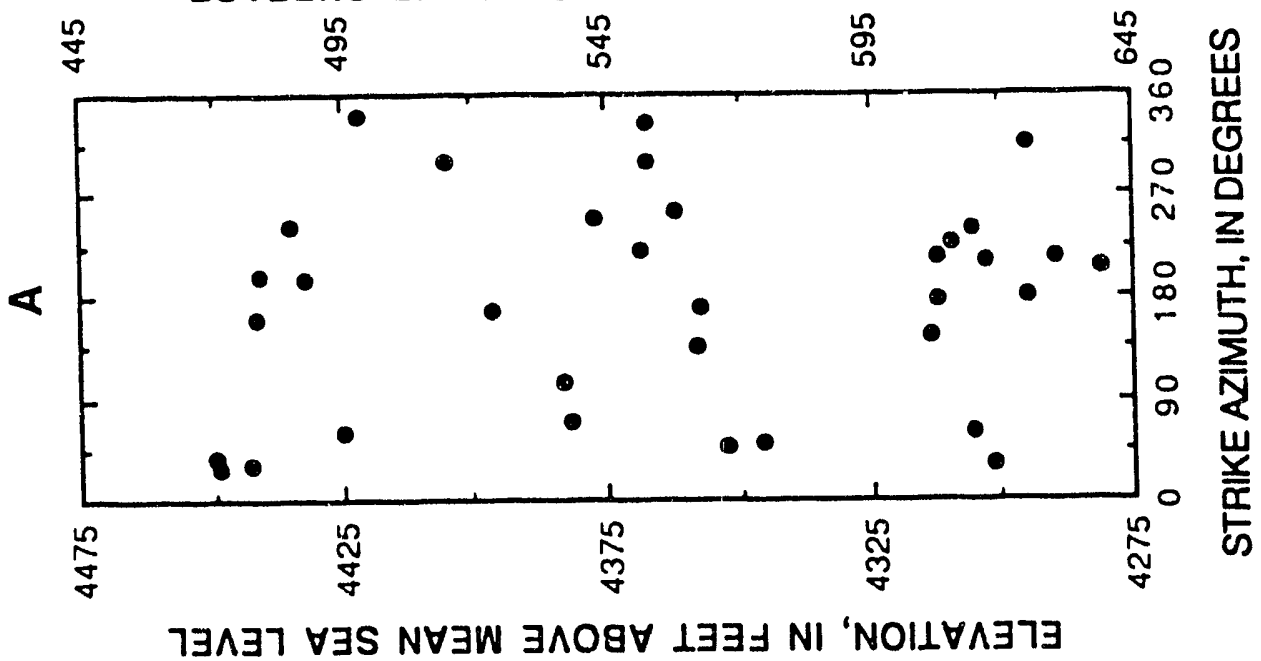

4

离已

aे

$\stackrel{\square}{\leftrightarrows}$

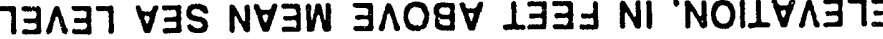




\section{Natural Circulation Patterns}

The vertical movement of fluid in a water well is of ten of primary importance to hydrogeologic studies. Such vertical flows are especially important in fractured-rock aquifers, where differences in hydraulic head between individual fracture zones can develop. These naturally occurring head differences can be used to evaluate potential for contaminant dispersal based on the effects of aquifer heterogeneity. Typically, vertical fluid velocity in a borehole is measured by means of an impeller flowmeter or is deduced through some type of tracer experiment. Impeller flowmeters commonly have a minimum velocity detection limit of approximately a few feet per minute, and tracer tests usually are designed to monitor natural hydraulic gradients and associated flows on the order of a few feet per day.

Hess (1986) developed a thermal flowmeter that fills the measurement gap between impellers and tracer tests. This logging instrument measures vertical fluid velocities in a borehole ranging from about an inch per minute to several feet per minute and distinguishes between upward and downward flow direction. The tool functions on the principle of temperature tag-trace; details of its operation and calibration are reported by Hess (1986). Over the past few years the tool's basic design has been modified and refined, and it has been successfully used in numerous ground-water applications (Paillet and others, 1987; Barrash and Morin, 1987; Hess and Paillet, 1990). The thermal flowmeter used at the INEL was equipped with an inflatable packer capable of being expanded to about 8 inches in diameter by means of a downhole, wireline-operated pump. This inflated packer serves as a flow concentrator, channeling flow from a larger cross-sectional area to a smaller one and increasing the sensitivity of the instrument to very slow fluid velocities.

The thermal flowmeter was initially employed in the three wells prior to pumping in an effort to monitor ambient, or natural, fluid circulation in each well. Estimates of volumetric flow are made by measuring directly the vertical fluid velocity and multiplying by the cross-sectional area of the borehole using diameters determined from the caliper log. Therefore, to calculate net mass exchange between the formation and the borehole at particular zones, values of both fluid velocity and borehole diameter need to be measured accurately. Correspondingly, measurements of fluid velocity were obtained only at depths where, according to the caliper and televiewer logs, the borehole diameter was relatively uniform. Flow measurements were obtained in well 46 on September 18, 1991, in the late morning, in well 44 on the same day in the late afternoon, and in well 45 on the following day in the early afternoon.

The flow results under natural conditions are listed in table 1 and are also presented graphically in the $\log$ composites of figures 3,4 , and 5 . These plots illustrate an excellent correlation between natural flow conditions in a borehole and the corresponding temperature profile. In the lower part of each well, where flow is small or even negligible, the temperature profile remains relatively undisturbed and represents the background geothermal gradient in this area. As upward flow becomes more significant nearer the surface, above approximately $580 \mathrm{ft}$, the temperature log reflects this increase in fluid velocity by approaching an isothermal state. 
Table 1.--Thermal-flowmeter measurements in wells 44,45 , and 46

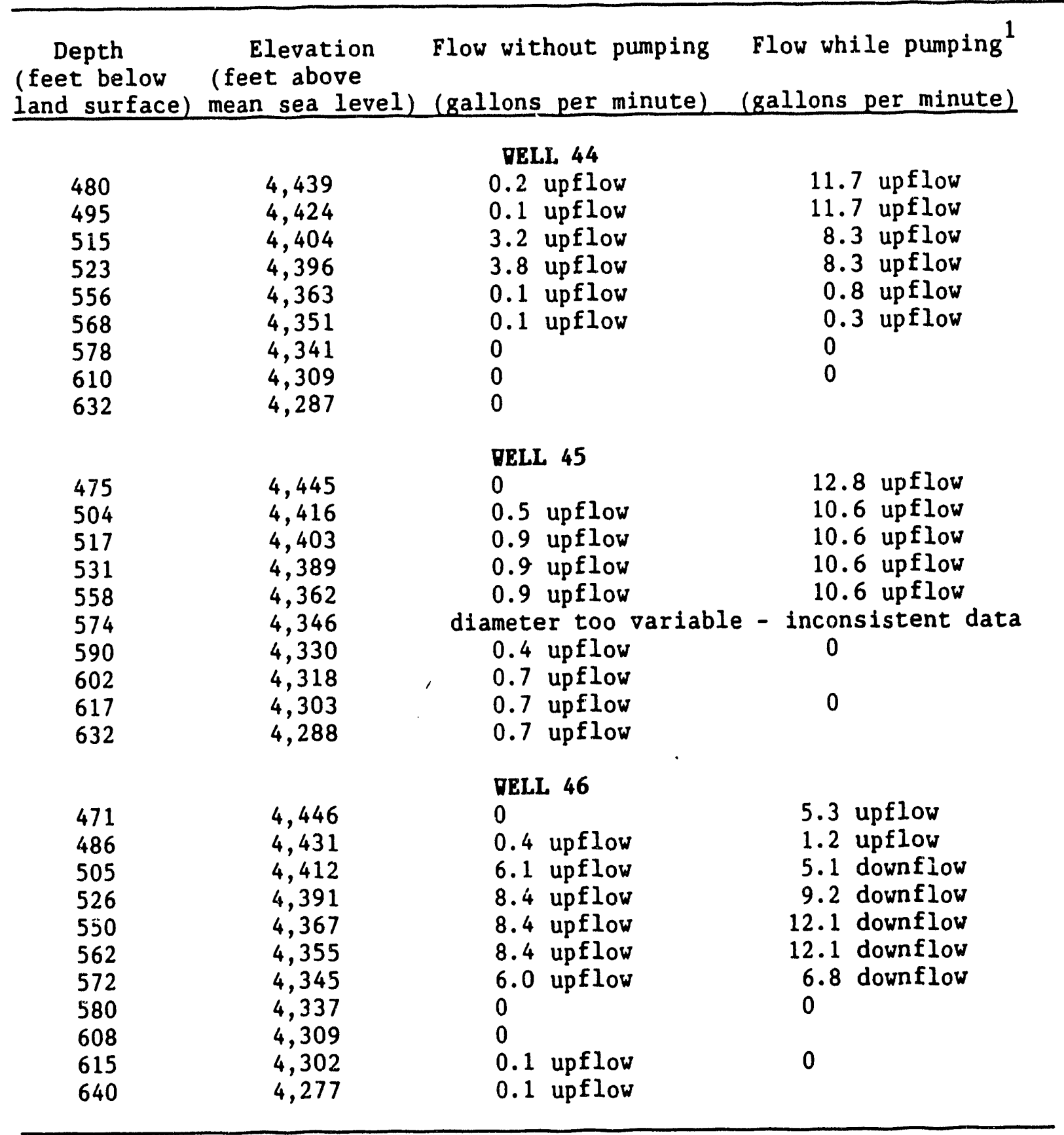

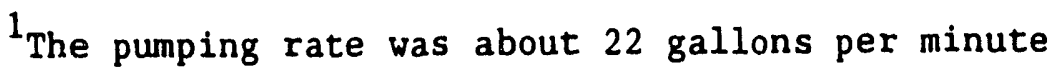


Interpretations of the natural circulation patterns for each well based on these data are incorporated onto the respective caliper logs and are presented in figure 10. Each well appears to contain upward circulation cells. In well 44, a very weak cell is detected in the uppermost part of the aquifer just below casing, and a broader, more vigorous cell occupies the central part of the well. Six different zones exhibit some evidence of mass exchange, with the majority of this fluid transfer occurring at three principal rubbly or fractured intervals $(4,370-4,381 \mathrm{ft}$ amsl; 4,397-4,404 ft amsl; and 4,406-4,421 ft amsl). There is no detectable flow below 4,340 ft, an elevation that marks the appearance of flow group I. A similar, but qualitative, conclusion was given by Anderson (1991), who suggested on the basis of geologic properties that ground-water movement at the ICPP might be concentrated in the zone just above flow group I.

Absolute flow rates measured in well 45 are the smallest of the three wells, less than $1 \mathrm{gal} / \mathrm{min}$, and both circulation cells are relatively weak. Upward flow is detected in the bottom of the hole. This upward movement fersists, though at a continually diminishing rate, across several fluid-loss zones until it completely ceases at about $35 \mathrm{ft}$ below casing (about 4,424 ft amsl). A fractured zone at an elevaton of 4,368-4,382 ft, where the borehole wall is significantly enlarged, displays no evidence of mass transfer and does not seem to influence the circulation pattern.

The general circulation pattern in well 46 appears to be similar to that in well 45, even though the absolute flow rate is almost an order of magnitude greater. Again, upward flow is detected at the bottom of the hole. Fluid rises across a few intervals of positive and negative mass transfer until it stops about $20 \mathrm{ft}$ below casing. Wells 45 and 46 exhibit a weak lipward circulation cell in the lower part of the holes and a

significant fluid contribution to the boreholes at about $4,350 \mathrm{ft}$; the fluid disperses back into the formation across several discrete intervals as it rises. In general, zones of fluid exchange seem to correlate with flow contacts, as identified from the caliper log, with one notable exception. As was the case with well 45, a major rubble or fractured interval $(4,360-4,375 \mathrm{ft}$ amsl) about $15 \mathrm{ft}$ thick appears in well 46; this zone does not affect natural circulation within the borehole.

\section{Hydraulic Conductivity Measurements}

A few days after flowmeter measurements had been obtained in wells 44 , 45, and 46 under ambient conditions, the thermal flowmeter was again deployed in each well. In this instance, a submersible pump was lowered above the flowmeter and secured in the well approximately $10 \mathrm{ft}$ below the water table. The pump was started and, after waiting 15-20 minutes for the drawdown to stabilize, a new series of flowmeter measurements was obtained at the same depths at which natural flow had been measured previously. Pumping rate at the surface was measured using a calibrated bucket and a stopwatch, and was determined to be about $22 \mathrm{gal} / \mathrm{min}$. Flow measurements were obtained in well 46 on September 21, 1991, in the late morning, in well 45 on the same day in the late afternoon, and in well 44 on the following day in the early afternoon. Flowmeter data obtained during pumping also are listed in table 1 and plotted in figures 3,4 , and 5 . 


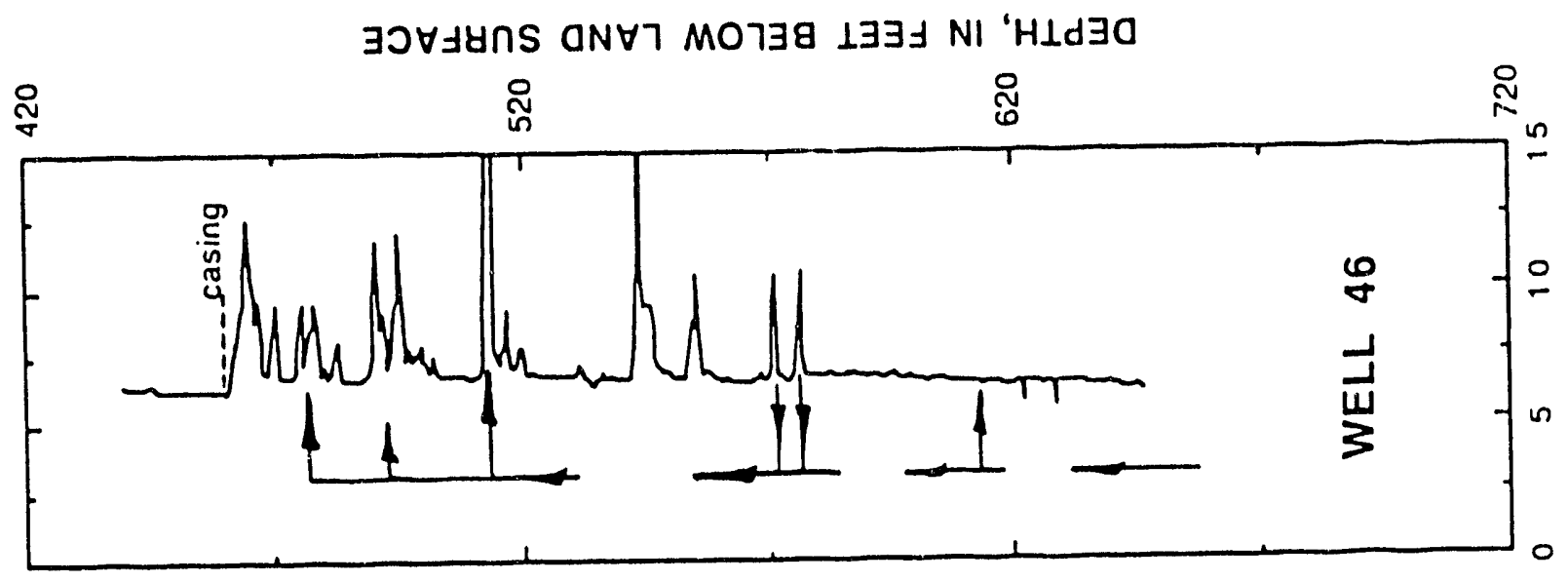

$\left[\begin{array}{l}0 \\ 0 \\ 0 \\ 0 \\ 0 \\ 0 \\ 0 \\ 0\end{array}\right.$

ง

-

岱

듀

on.

䠉

的

a

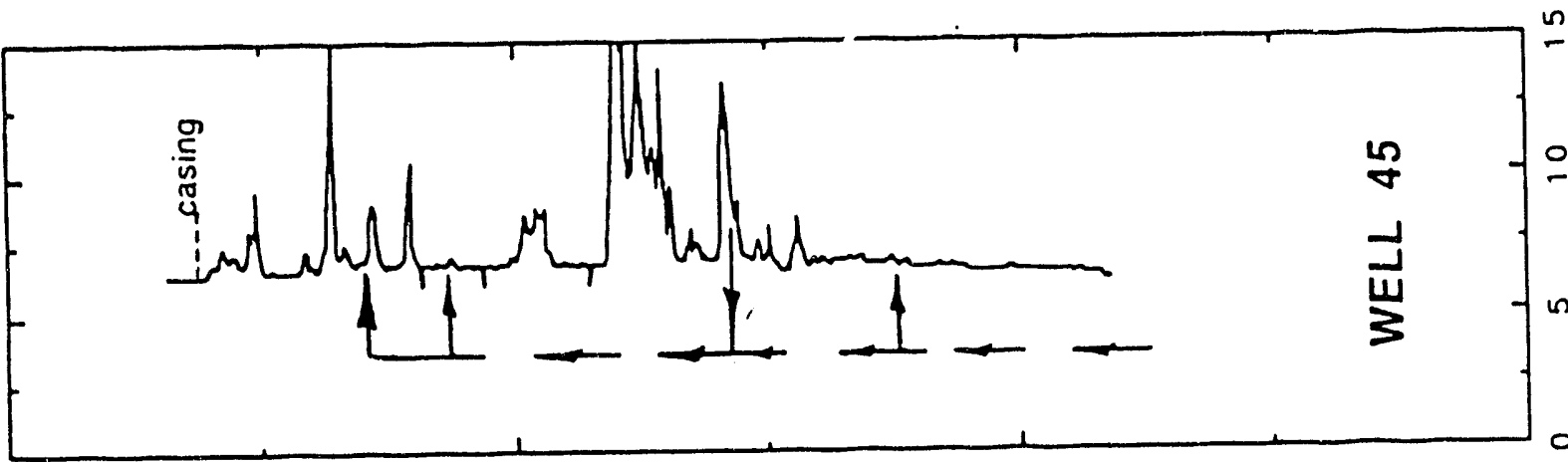

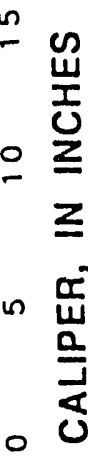

喟

莺

出 巡

0 㟧

至

त)

(⿻)

㐘

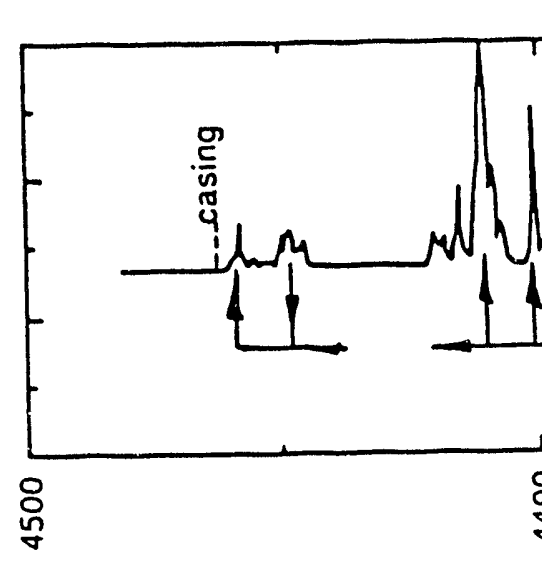

$\stackrel{n}{2}$

웜

幽
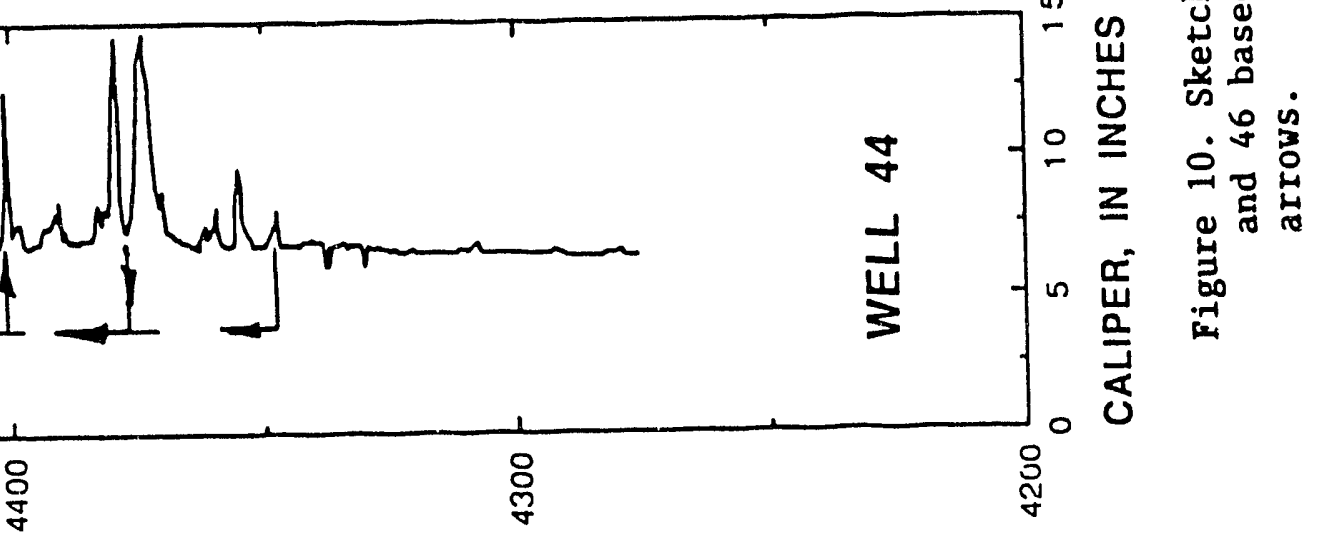

ষ্ণ

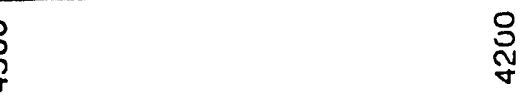

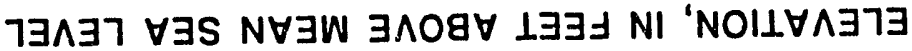


The vertical distribution of hydraulic conductivity may be computed at a vertical scale determined by the spatial frequency of flow measurements. This is accomplished by means of a simple and innovative technique developed by Hufschmied (1984), which utilizes pumping at constant rate and concurrent flow and pressure measurements to construct a detailed profile of hydraulic conductivity. This field method has been applied to a variety of geologic formations (Morin and others, 1988; Rehfeldt and others, 1988; Hess, 1989), and comparison of hydraulic conductivity values estimated from this method to those of other standard, established field methods has been excellent (Molz and others, 1989). The hydrologic system is considered to be a confined or semi-confined aquifer in this analysis. This assumption is based on: (1) barometric efficiencies reported by Morris and others (1963), which indicate that hydraulic continuity to the surface is impeded, and (2) natural circulation patterns in the boreholes that indicate differences in hydraulic heads between individual fracture zones.

After constant-rate pumping has proceeded for a period of time sufficient to ensure that the accompanying drawdown has reached a quasi-steady state, flowmeter and pressure measurements are obtained as a function of depth to specifically measure the vertical distributions of fluid velocity and hydraulic head. The formation under investigation is assumed to be composed of numerous horizontal layers of arbitrary thickness, H (fig. 1I), and flow from each uniform layer is assumed to be horizontal and isotropic. The volumetric flow rate $\left(\Delta Q_{i}\right)$ from the aquifer through each interval $\underline{i}$ is, from conservation of mass, the difference between the flow rates traveling up the borehole measured above and below the zone of interest. From figure 11,

$$
\underline{\underline{Q}}_{\underline{i}}=\underline{Q}_{2}-\underline{Q}_{3}
$$

The change in borehole pressure adjacent to layer $\underline{1}\left(\Delta \underline{P}_{j}\right)$ is the pressure decrease below hydrostatic pressure that is required to force fluid out of the interval $\underline{i}$. This decrease can be measured directly at the surface as the change in water level due to pumping when the pumping rate is low and flow is laminar. When the pumping rate is relatively high and flow becomes turbulent, frictional head losses in the well become significant; consequently, a pressure log must be obtained as a function of depth to adequately define the vertical distribution of $\Delta \underline{P}_{i}$ (Morin, 1988). Once the flow out of each interval and the head required to induce that flow are known, hydraulic conductivity can be computed by using the expression derived by Cooper and Jacob (1946, p. 527, eq. 2):

$$
\underline{K}=(\Delta \underline{Q} / 4 \pi \underline{H} \underline{\underline{P}}) \ln \left(2.25 \underline{\mathrm{KHt} / \underline{R}^{2}} \underline{\mathrm{S}}\right)
$$

where $\underline{K}$ is hydraulic conductivity (in dimensions of $\underline{L} / \underline{T}$ ); $\Delta \underline{Q}$ is horizontal volumetric flow rate out of formation $(\underline{L} / T) ; \underline{H}$ is thickness of interval $(\underline{L}) ; \Delta \underline{P}$ is change in head from initial static condition ( $\underline{L})$; $\underline{t}$ is time since onset of pumping ( $\underline{T})$; $\underline{R}$ is borehole radius $(\underline{L})$; and $\underline{S}$ is formation storativity (dimensionless). Values of porosity estimated from the neutronporosity logs were used to compute storativity for each individual interval of thickness $\underline{H}$. Equation 2 is valid for large time, or when

$$
\underline{\mathrm{R}}^{2} \underline{\mathrm{S}} / 4 \underline{\mathrm{KHT}}<0.01
$$




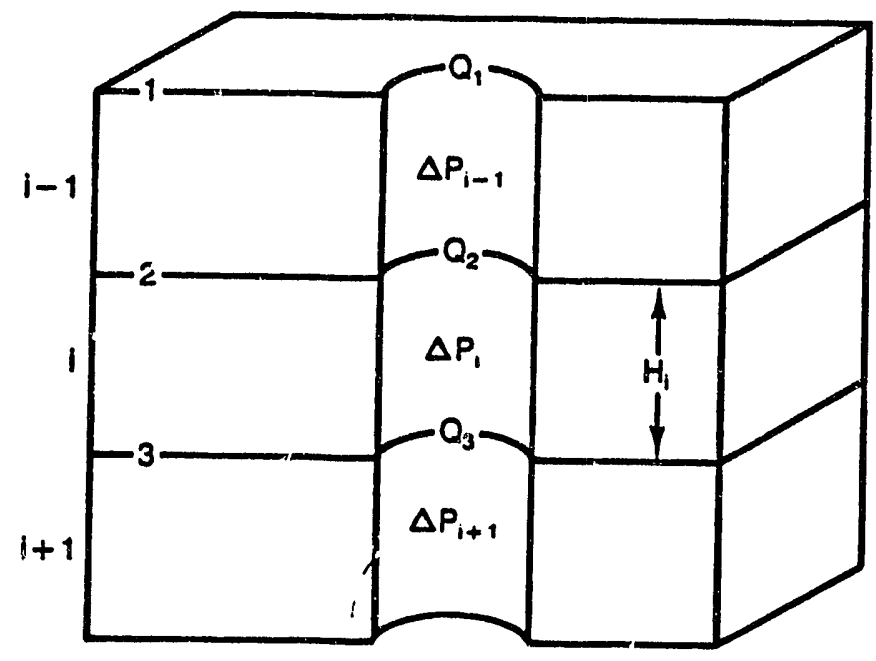

Figure 11. Horizontally layered hydraulic conductivity model (refer to equations 1 and 2 in text). 
Examination of figure 11 illustrates that this pumping/logging approach is equivalent conceptually to numerous, miniature straddle-packer tests being performed simultaneously throughout the well. The technique is not dependent on proper seating of packers against the borehole wall, and it can therefore be employed regardless of the physical condition of the wellbore. The technique is capable of quantifying hydraulic conductivities over 2 to 3 orders of magnitude, limited primarily by the measurement range of the flowmeter and by the precision to which the drawdown can be measured.

In the case of the INEL wells, maximum fluid velocities in the borehole below the pump were still slow enough to remain laminar (Reynolds number Re 5,800; e.g., see White, 1979). Consequently, without a clear indication of turbulent flow and the frictional head losses that accompany it, the drawdown due to pumping can be assumed to propagate uniformly throughout the well, and the pressure term in equation $2\left(\Delta \mathrm{P}_{i}\right)$ is constant. Monitoring of drawdown was attempted in well 46 during pumping, but none was detected; drawdown was less than the $0.03-\mathrm{ft}$ resolution limit of the pressure transducer placed in the well. Direct measurements of drawdown were not made in wells 44 and 45 during this study, and the estimates of drawdown that are necessary to compute hydraulic conductivity were taken from previous transmissivity studies performed at this site (D.J. Ackerman, Hydrologist, USGS, written commun., 1991).

In this previous field work, a drawdown of $0.01 \mathrm{ft}$ was recorded in well 44 while pumping at $24 \mathrm{gal} / \mathrm{min}$. Pumping well 45 at $24 \mathrm{gal} / \mathrm{min}$ resulted in a 0.25 - ft drawdown, and pumping well 46 at $28 \mathrm{gal} / \mathrm{min}$ produced less than 0.01 $f t$ of head change. The magnitude of drawdown recorded in well 44 is so small that it is approximately equal to the precision of the measurement $(0.01 \pm 0.01 \mathrm{ft})$. Correspondingly, original estimates of hydraulic conductivity may be reduced by one half (based on a drawdown of $0.02 \mathrm{ft}$ ) or may approach infinity (based on no detectable drawdown). In order to represent this large nonlinear error, uncertainty may be expressed logarithmically in terms of orders of magnitude (Ackerman, 1991). The uncertainty in these calculations of hydraulic conductivity and, consequently, in estimates of transmissivity is assumed to be \pm 0.4 orders of magnitude. A similar range of uncertainty was used by Ackerman (1991) in his analysis of transmissivity data from wells in the INEL.

The hydraulic conductivity distributions computed from the field data for wells 44 and 45 are depicted in figure 12. The values of hydraulic conductivity were averaged over the designated thickness of each interval, as determined by the locations of the flowmeter measurements. Although permeable zones in this heterogeneous aquifer are likely concentrated at thin, rubbly basalt-flow boundaries, fluid flow measurements in the wells were not obtained at this scale of vertical resolution. Thus, values of hydraulic conductivity are integrated over thicker sections that encompass permeable and impermeable lithologies.

The absolute values of hydraulic conductivity determined in this analysis may vary significantly due to measurement uncertainties, but their relative values should remain largely unchanged. Thus, for well 44, the hydraulic conductivities of seven individual layers are determined that span approximately two orders of magnityde. These sum to a cumulative transmissivity of about $890,000 \mathrm{ft}^{2} / \mathrm{d}$ for that portion of the Snake River 


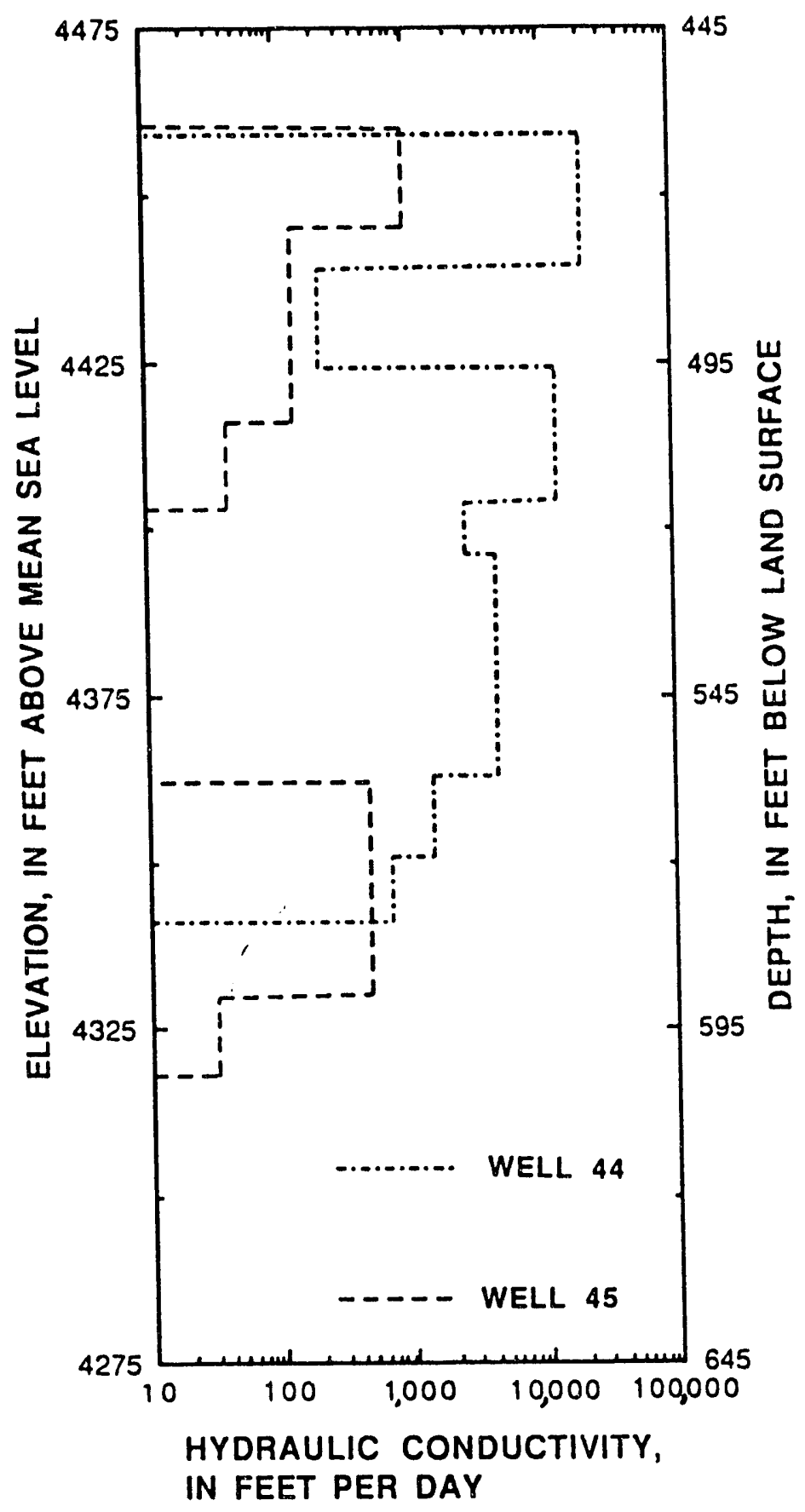

Figure 12. Graph showing vertical distribution of hydraulic conductivity in wells 44 and 45 . Values of hydraulic conductivity have an uncertainty of \pm 0.4 orders of magnitude. 
Plain aquifer that is penetrated by this well. With an assumed uncertainty of \pm 0.4 orders of magnjtude, this transmissivity falls within the range of 354,000 to $2,240,000 \mathrm{ft}^{2} / \mathrm{d}$. As inferred from the natural circulation pattern for this well (fig. 10), the enlarged zones identified in the caliper log control the distribution of hydraulic conductivity. Where these intervals disappear below 4,340 ft amsl, the hydraulic conductivity becomes too small to quantify.

In well 45, only five permeable zones are identified with hydraulic conductivities that range over roughly $11 / 3$ orders of magnitude. These sum to a cumulative transmissivity of $35,000 \mathrm{ft} / \mathrm{d}$ for that portion of the Snake River Plain aquifer that is penetrated by this well. Given the assumed range of yncertainty, this transmissivity estimate is between 14,000 and $88,000 \mathrm{ft}^{2} / \mathrm{d}$. As with well 44, the major permeable intervals correlate with the fractured contact zones and subsequently disappear in the lower part of the well, with one notable exception. The interval between about 4,370 and 4,400 ft amsl is marked by substantial borehole enlargements and apparently exerts no influence on the natural fluid circulation in the borehole (fig. 10). This interval is also atypical in that it does not have fluid exchange during pumping and, therefore, has no measurable hydraulic conductivity. Thus, although fluid transfer between the borehole and the formation generally is restricted to fractured contact zones, not all contacts are permeable.

Flow data obtained during pumping in well 46 (table 1) were completely unexpected, and measurements were repeated several times to verify the results. As can be seen in the flow distribution presented in figure 5 , borehole fluid in most of the well actually moved downward once pumping began. At the time this field work was being conducted, supply well CPP2 at the ICPP was pumping on a cycle of approximately 2 hours out of every 6 hours. This well is approximately $0.5 \mathrm{mi}$ north-northeast of well 46 (fig. 2 ). The pump in well CPP2 is actuated by a water-level sensor in the process water-storage system and pumping records are in the form of drum charts that are accurate to the nearest one-half hour. Of the six sets of flowmeter measurements reported in this study (without and with pumping in each of three wells), the measurements obtained while pumping in well 46 clearly coincide with pumping at well CPP2.

The reversal of gradient from upward flow to downward flow in well 46 with pumping at well CPP2 provides evidence of hydraulic communication. This interference precludes any attempt to compute hydraulic conductivity for well 46 with the existing flow data. Well-construction information (U.S. Department of Energy, 1990) and stratigraphic data suggest that the saturated open intervals in well CPP2 and in wells 44,45 , and 46 intercept basalt flows from groups $E$ to $H$ and from group $I$ (fig. 13) (Anderson, 1991, fig. 7). Also, individual and/or aggregate units appear to dip southward from well CPP2 to wells 44, 45, and 46 (fig. 7) (Anderson, 1991, fig. 22).

Using these stratigraphic interpretations and the observed hydraulic connections between wells, a working hypothesis can be presented to explain the presence of overall upward gradients and two upflow cells in wells 44 , 45, and 46. If permeable zones are southward-dipping layers that are hydraulically continuous individually and separated by less permeable layers, then upward gradients are expected in the down-dip regions of 


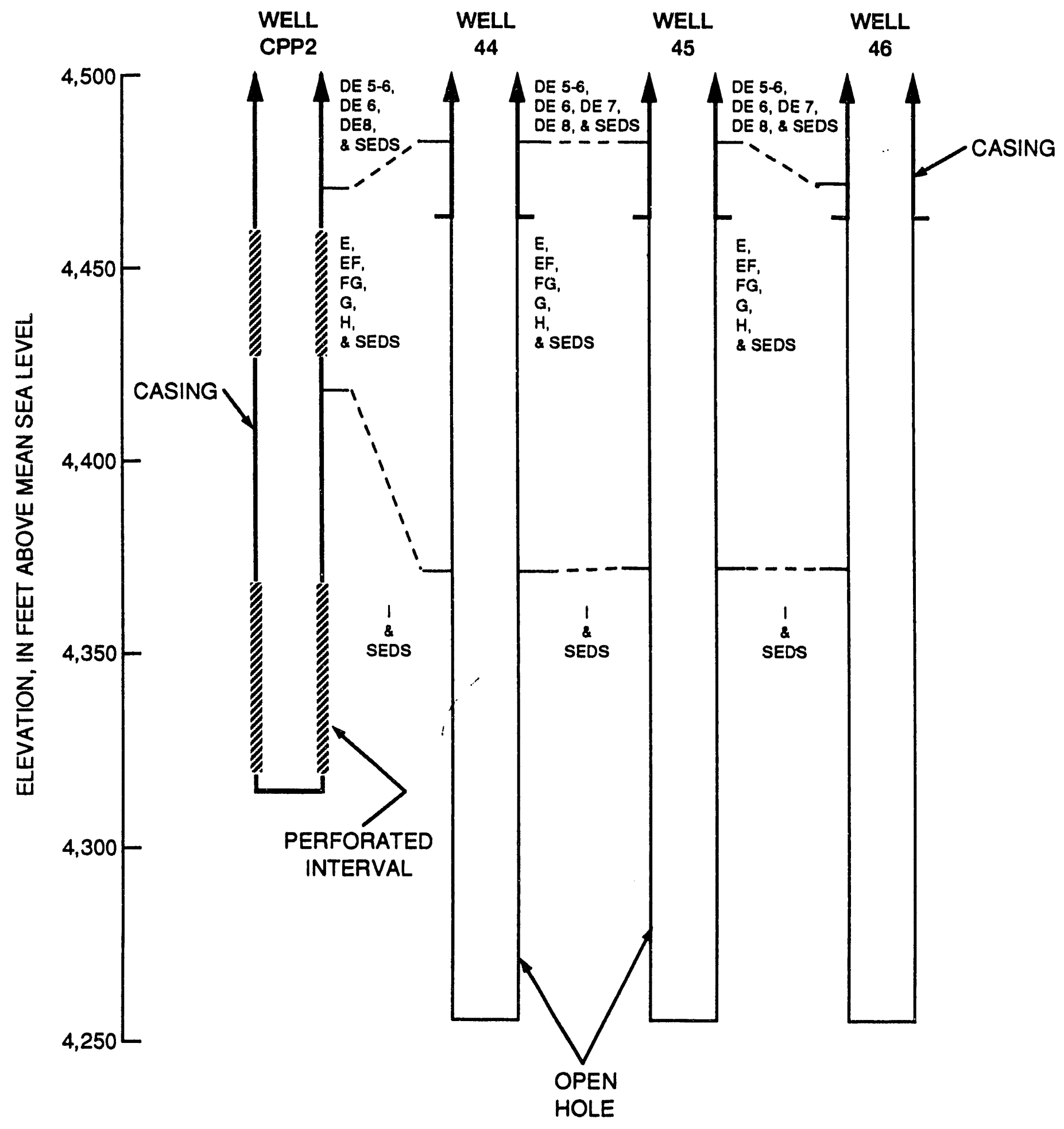

Figure 13. Diagram showing correlation of stratigraphy for wells 44, 45, and 46 (from Anderson, 1991) with construction diagram of well CPP2 located near the Idaho Chemical Processing Plant. 
permeable layers such as the area encompassed by wells 44,45 , and 46 relative to well CPP2. Separate circulation cells may occur where vertical leakage is severely limited across stratigraphic boundaries (perhaps the interbed and upper contact of group I). In this scenario, gradient reversals occur in well 46 when pumping in supply well CPP2 drops the hydraulic head in well CPP2 below that in well 46. Unfortunately, waterlevel measurements are not possible in well CPP2 at this time (1991).

The zone of high hydraulic conductivity in wells 44 and 45 occurs immediately below casing, and below an elevation of about 4,330 ft hydraulic conductivity becomes too small to quantify by this field method. The quantification of hydraulic conductivity is constrained by the resolution of the thermal flowmeter, which is about $0.1 \mathrm{gal} / \mathrm{min}$, and by the ability to monitor the drawdown. Minimum measurable values of hydraulic conductivity are about $300 \mathrm{ft} / \mathrm{d}$ for well 44 and $10 \mathrm{ft} / \mathrm{d}$ for well 45 . Thus, the distribution of hydraulic conductivity presented in figure 12 for well 44 is somewhat deceiving in that it shows the hydraulic conductivity of this aquifer to be negligible below $4,340 \mathrm{ft}$ when, in fact, values of hydraulic conductivity may be as high as $300 \mathrm{ft} / \mathrm{d}$ and be below the detection limit of the field method.

Nevertheless, the pumping/logging results are effective in separating the overall transmissivity into distinct horizontal layers that illustrate the relative changes in hydraulic conductivity with depth. The hydraulic conductivity data presented in figure 12 indicate that zones of significant permeability at this particular site, as determined in wells that penetrate the upper $190 \mathrm{ft}$ of the aquifer, are restricted to the uppermost $120 \mathrm{ft}$ of the aquifer. Comparison of the distribution of in-hole flow (table 1) with stratigraphic data (fig. 13) suggests that significant changes in in-hole flow regimes occur at, or within $25 \mathrm{ft}$ below, the interpreted contact between flow groups E-H and I (i.e., at about 550 to $575 \mathrm{ft}$ bls). Major decreases in in-hole flow and hydraulic conductivity in the lower portions of these wells should not be interpreted as indicating the base of the aquifer. The effective base of the Snake River Plain aquifer was estimated to be between 445-825 ft below the water table at one location at the INEL (Mann, 1986) and at about 1,700 ft bls at another site approximately 3 miles east of the ICPP (Anderson, 1991).

\section{Gamma-spectral analysis}

Natural radioactivity in rocks originates mainly from potassium $\left({ }^{40} \mathrm{~K}\right)$ and daughter products of the decay series of uranium and thorium. Each of the natural sources of radioactivity has a characteristic energy signature that distinguishes it from other sources (fig. 14). The distinctive energy peaks associated with several common anthropogenic $\gamma$-emitting isotopes are illustrated in figure 15. Gamma spectra were collected at several depths in wells 44,45 , and 46 in an attempt to identify the primary sources of radioactivity at this study site. 


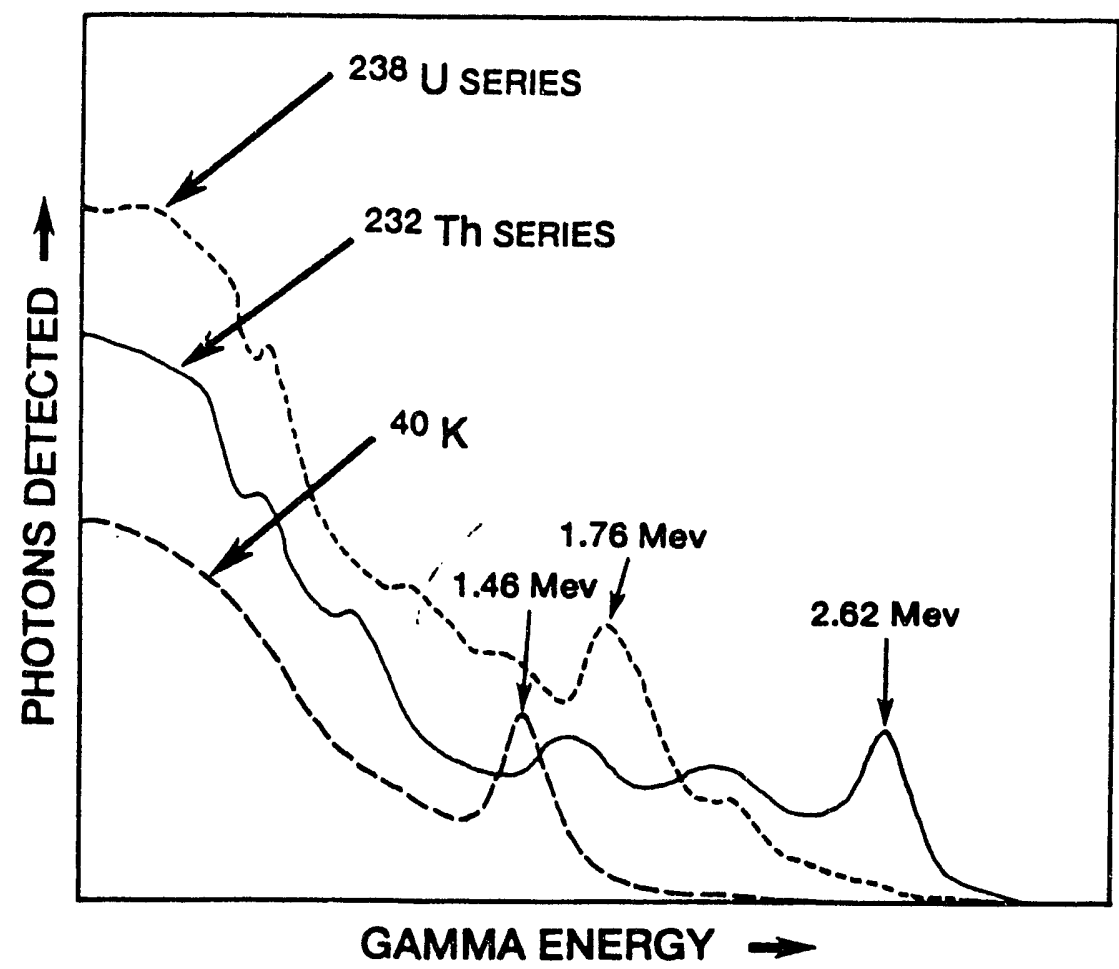

Figure 14. Diagram showing characteristic gamma-energy signatures of the prominent, naturally occurring radionuclides uranium ( $\left.{ }^{238} \mathrm{U}\right)$, thorium $\left({ }^{232} \mathrm{Th}\right)$, and potassium $\left({ }^{40} \mathrm{~K}\right)$. Gamma energy scale is in million electron volts $(\mathrm{MeV})$. 


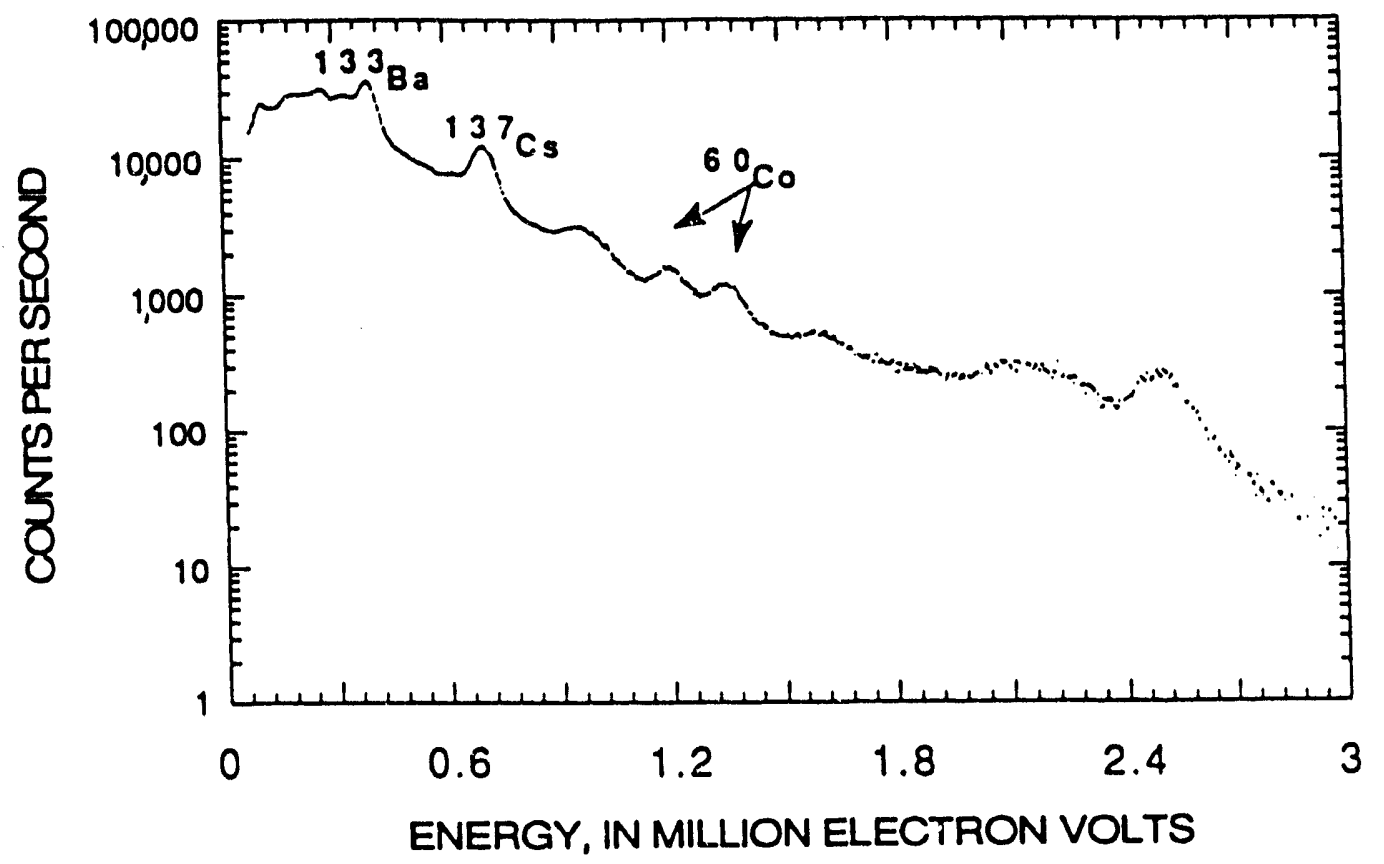

Figure 15. Energy spectrum showing characteristic energy peaks associated with several anthropogenic, $\gamma$-emitting isotopes barium $\left({ }^{133} \mathrm{Ba}\right)$, cesium $\left({ }^{137} \mathrm{Cs}\right)$, and cobalt $\left({ }^{60} \mathrm{Co}\right)$. 
The intensity and energy of natural and anthropogenic $\gamma$-emitting radioactivity were measured while holding the gamma-spectral logging probe stationary in the well for a specified period of counting time. The downhole gamma spectra analyzed in this study encompass a range of gamma energy from 0 to approximately 3 million electron volts ( $\mathrm{MeV})$. The scintillation detector is a sodium-iodide crystal doped with thallium; this type of detector has a high counting efficiency but a poor energy resolution. Detailed discussions regarding the principles of borehole gamma spectrometry are presented by Keys and others (1979) and by Schimschal (1980). General information concerning the gamma-spectral data sets collected during this study is listed in table 2. This method is particularly effective in assessing the migration of radioactivity in the unsaturated zone at this site because it can measure activity behind well casing.

Natural gamma logs obtained in wells 44,45 , and 46 are presented in figure 16. Locations at which gamma-spectral data were collected were selected on the basis of anomalously high peaks in these gamma logs; corresponding sampling depths are indicated by circles in figure 16. The majority of the high radioactivity identified from these natural-gamma paaks in all three wells and subsequently recorded for spectral analysis was contributed by ${ }^{40} \mathrm{~K}$. A strong potassium peak is clearly visible in all 13 spectra, an example of which is shown in figure 17. Gamma-energy levels measured on core samples from nearby wells are low. Low levels are commonly measured in basalts and higher levels are associated with silicic volcanic ash and welded tuff (Barraclough and others, 1965).

One notable exception to this general trend of natural-gamma peaks corresponding to high levels of $40 \mathrm{~K}$ can be seen in the gamma spectrum obtained at a depth of $32 \mathrm{ft}$ in well 45 . This spectrum, which identifies the presence of cesium-137 ( $\left.{ }^{137} \mathrm{Cs}\right)$, is presented in figure 17 along with its point-source calibration counterpart. The counting time for the development of this spectrum was only 500 seconds, yet the total integrated counts are comparable to the total counts recorded at other depths for 1,000 seconds (table 2). A background reference spectrum taken at a depth of $544 \mathrm{ft}$ in well 45 was subtracted from the spectrum collected at $32 \mathrm{ft}$ to produce a residual spectrum (fig. 18) in which the ${ }^{137} \mathrm{Cs}$ peak at $0.662 \mathrm{MeV}$ clearly emerges. ${ }^{137} \mathrm{Cs}$ has a half-life of 30 years.

The natural gamma response in well 45 at a depth of $32 \mathrm{ft}$ is the highest measured in any of the wells. The driller's logs indicate that this interval consists of a sandy clay layer approximately $20 \mathrm{ft}$ thick that does not appear in either of the other two wells. It appears that the high gamma activity identified at this depth is due to a combination of the nineralogical properties of clay and the contamination from an anthropogenic isotope. Because energy calibrations were not recorded and stored during the field operations, specific concentrations of any of the isotopes cannot be determined. Radiometric analyses of core samples recovered from this depth would be required to properly calibrate and compute concentrations. However, core samples are not available for wells 44,45 , or 46 , which were drilled by the cable-tool method in 1957-58. 
Table 2.--General information on gamma spectra from wells 44, 45, and 46

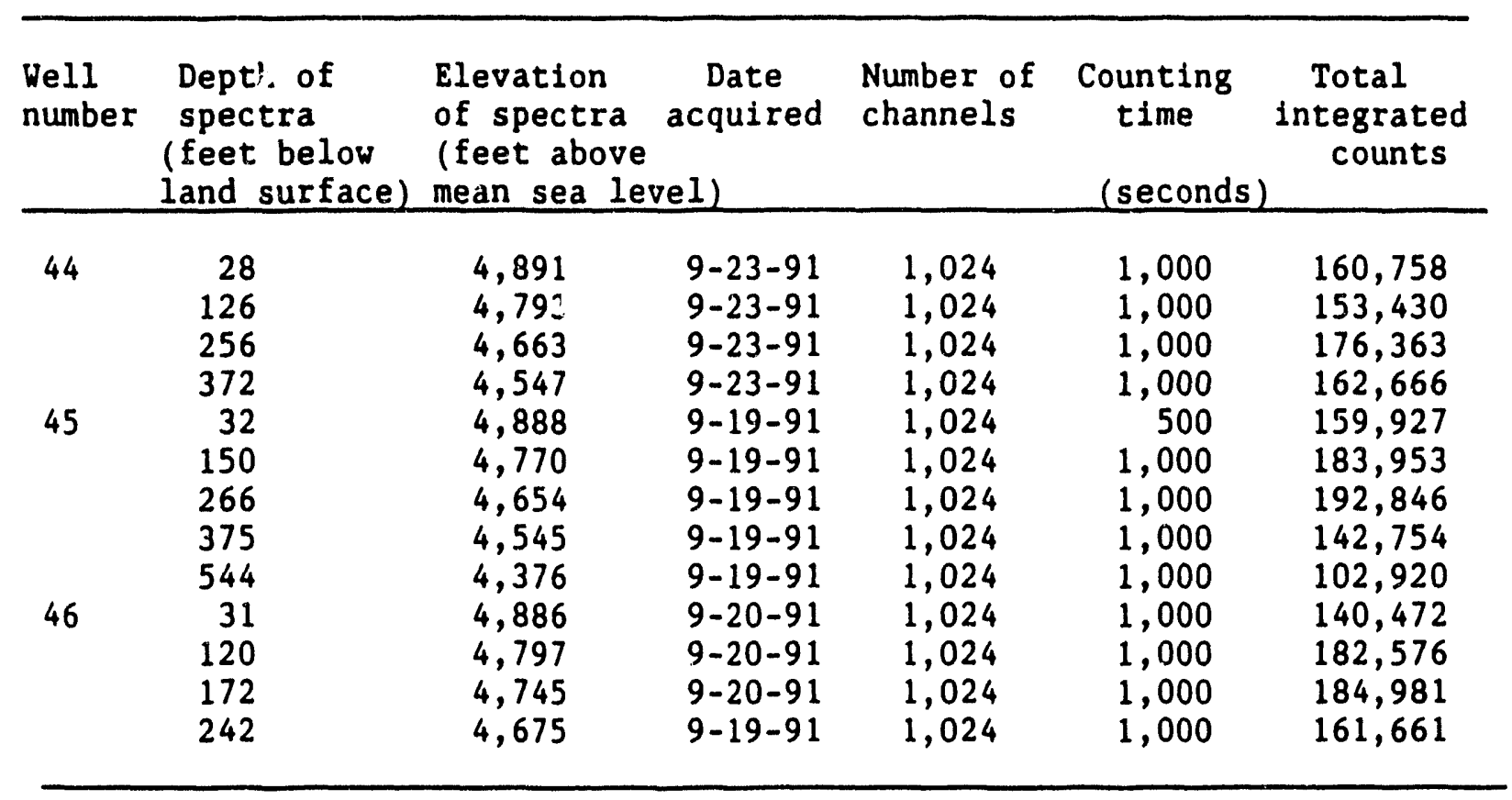




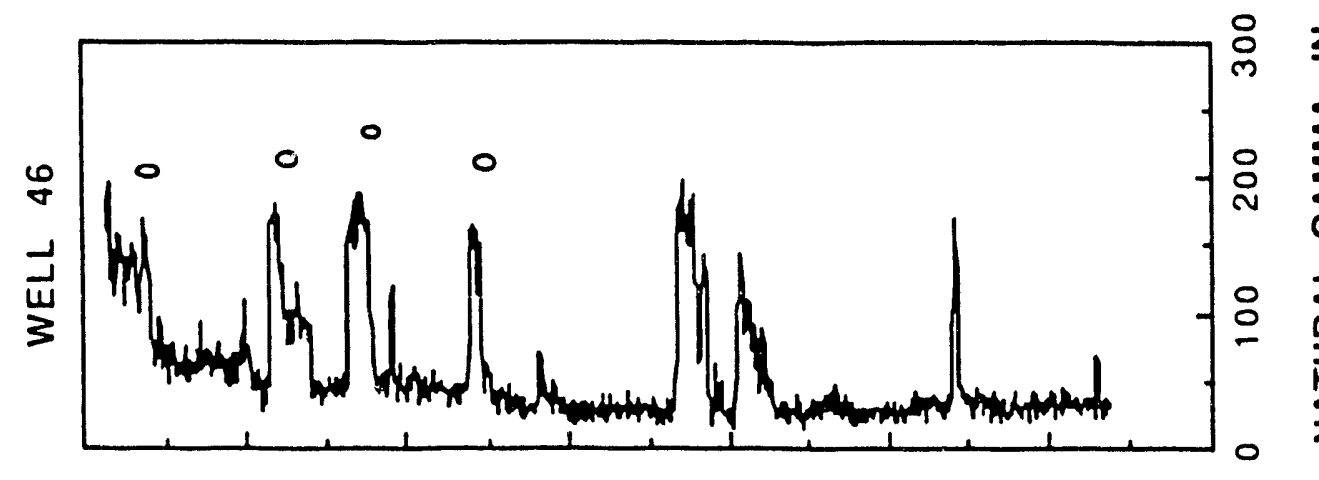

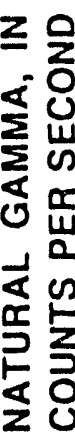

อัด

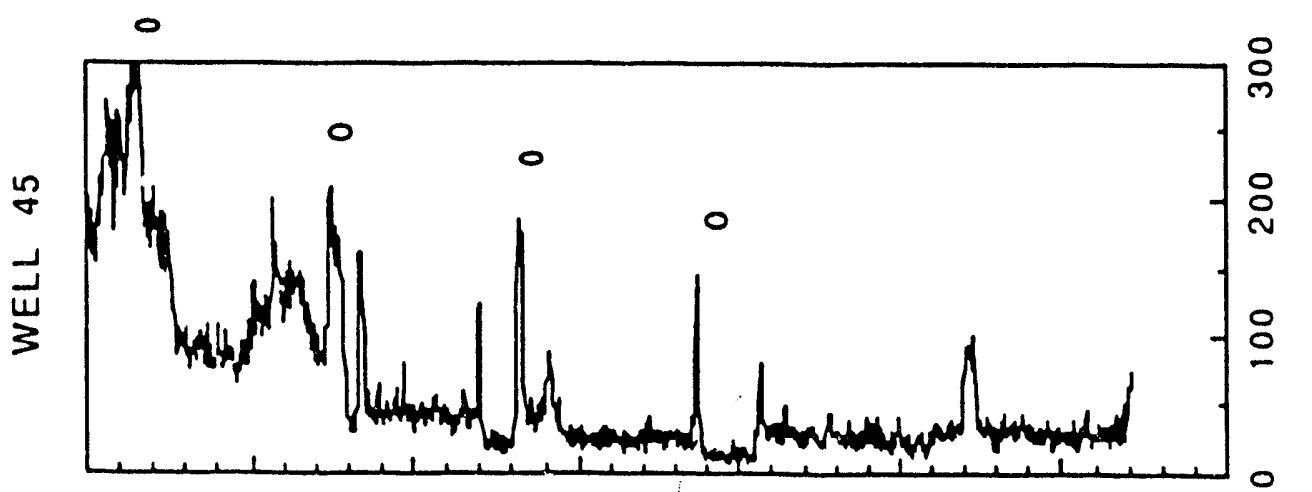

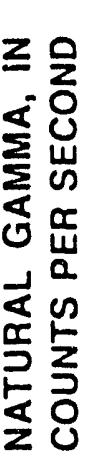

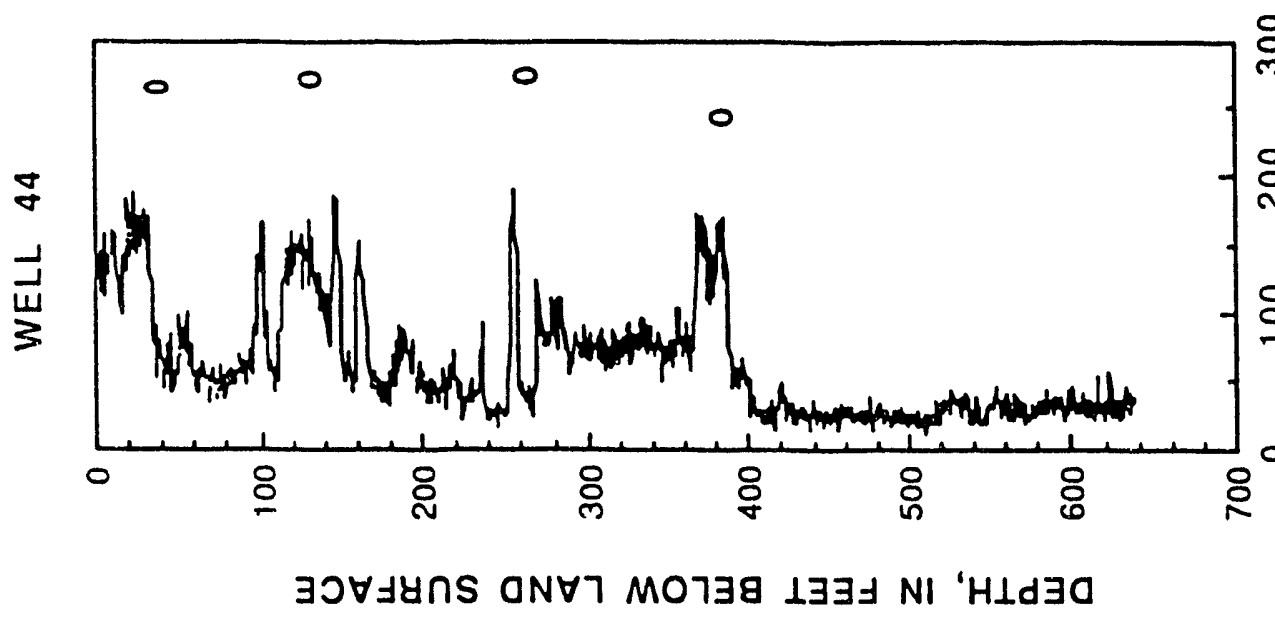

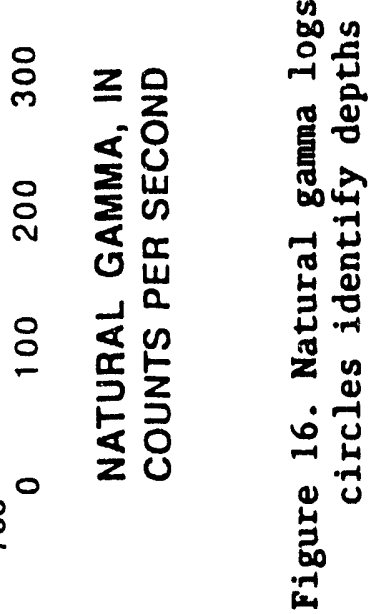




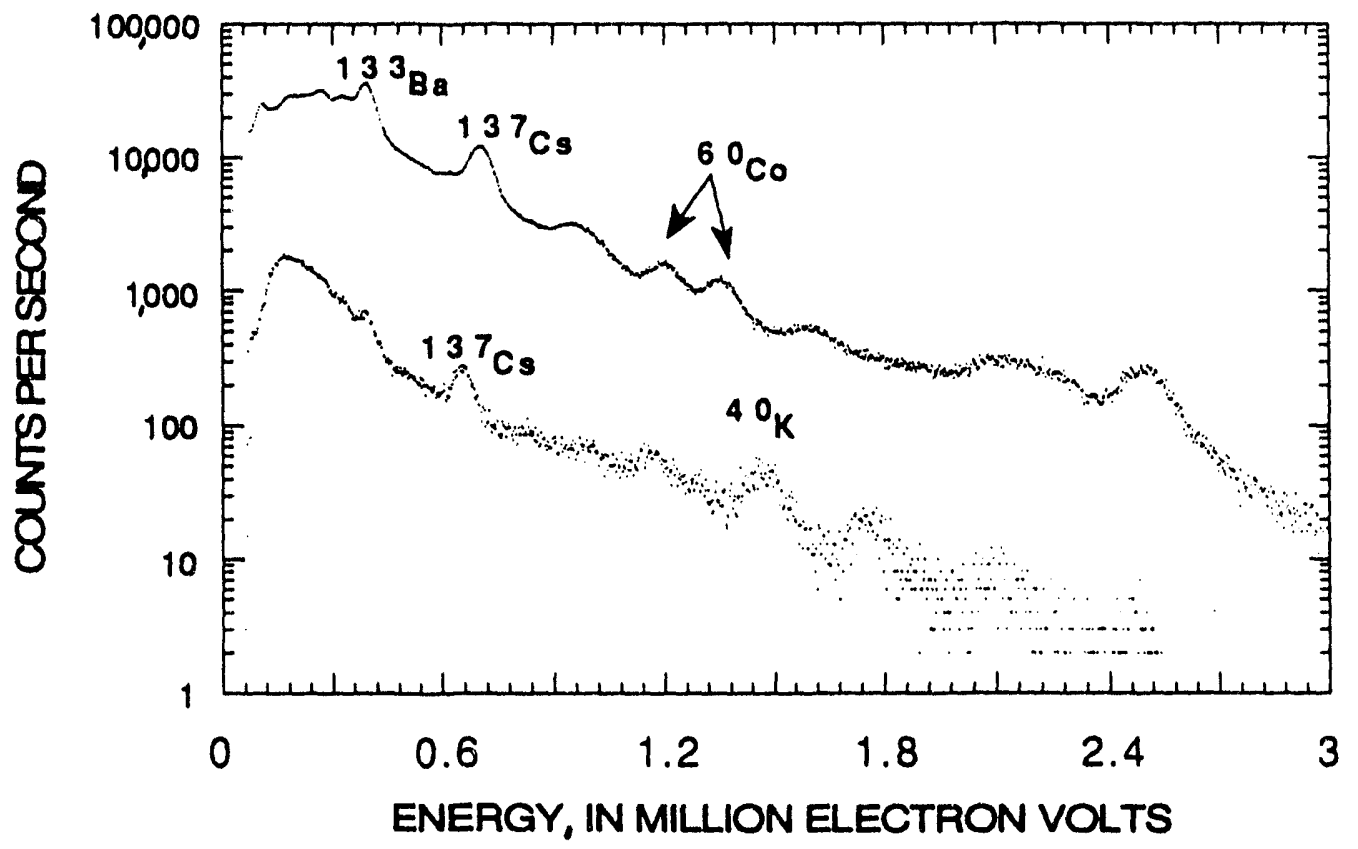

Figure 17. Graph showing energy spectrum (lower) obtained at a depth of 32 feet in well 45 compared to the point-source calibration spectrum (upper). Symbols are defined in figures 14 and 15. 


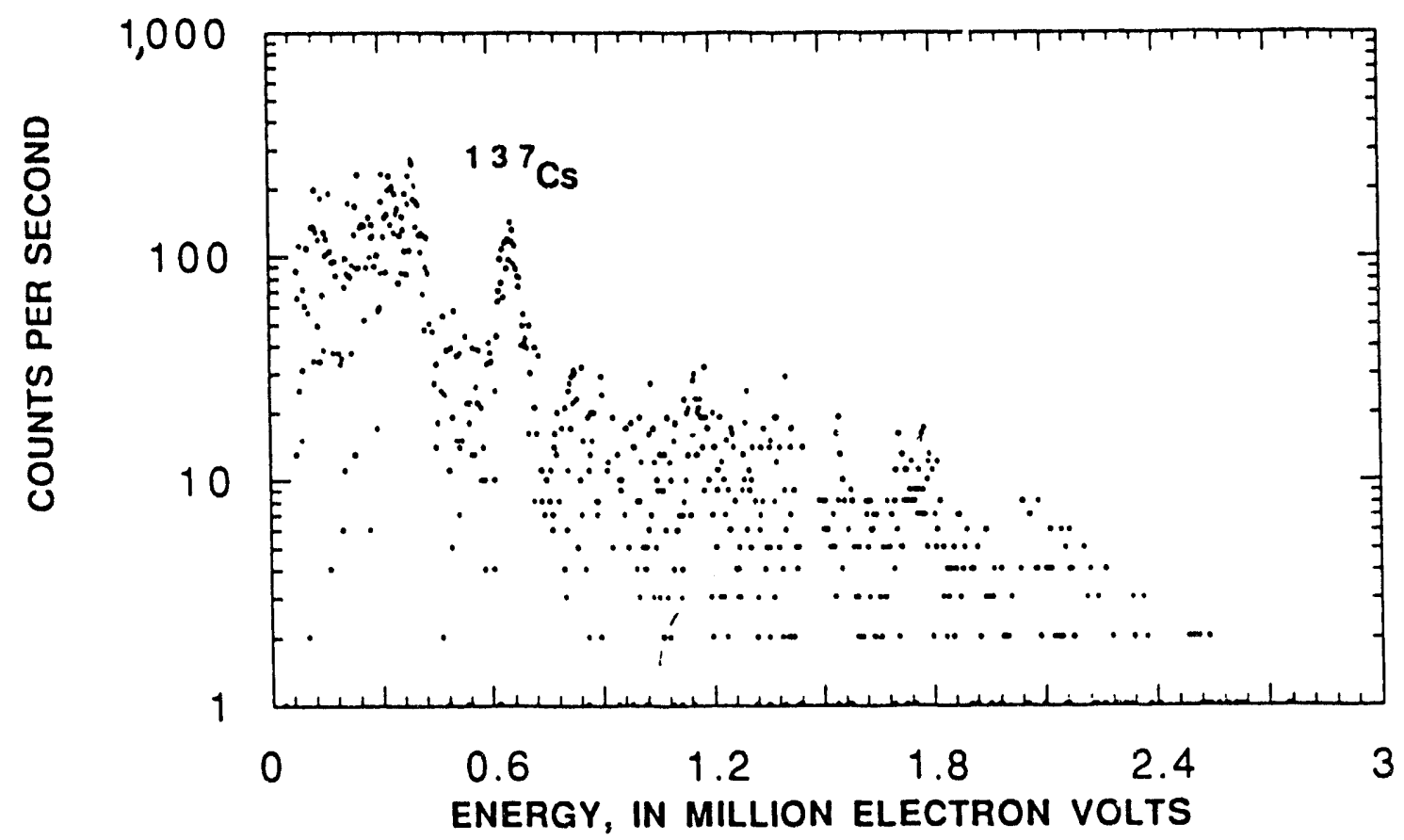

Figure 18. Graph showing residual energy spectrum produced by subtracting background reference spectrum from lower spectrum shown in figure 17 . 


\section{Multiple-spacing neutron experiment}

Neutron logging is a long-established method in geophysical investigations. Logging is performed by using a radioactive source to provide a steady flux of high-energy neutrons ( 1 to $15 \mathrm{MeV}$, depending on source type) and by subsequently measuring the flux of neutrons being scattered back to a detector located at some distance from che source. It is assumed that the neutrons are scattered and slowed in a series of collisions with the nuclei of atoms located around the source-receiver pair. The effective volume being sampled is assumed to depend on the separation of the source and receiver and the average radial penetration of the neutrons into the surrounding materials (Hearst and Nelson, 1985).

Consideration of the typical source and receiver configuration in a geophysical logging tool indicates that measurement of neutron flux attenuation given in terms of the slowing-down length, $\underline{L}$, is not simple and direct. L is defined as the root mean square distance traveled by neutrons in reaching the thermal energy level of $0.1 \mathrm{eV}$. L is usually measured using one of two different approaches, each incorporated into two different logging-tool configurations: the conventional neutron porosity-logging configuration and the moisture-meter configuration. In the conventional porosity-logging configuration, source-receiver separations are relatively large and the measurement is based on the flux of neutrons scattered back to the detector. The greater the length, $\underline{L}$, and the smaller the moisture content of the formation, the greater the measured flux in neutron counts per second.

In the soil-moisture-meter configuration, the source is very close to the detector, and the measurement no longer depends on backscatter of neutrons. Instead, the detector measures the flux of thermal neutrons in the immediate vicinity of the source. Because neutrons are slowed by interaction with water, the measurement is inversely proportional to $\underline{L}$ or directly proportional to moisture content and applies to the immediate vicinity of the neutron source. One of the main drawbacks with this configuration is that the short source-receiver spacing usually corresponds to a very small volume of investigation. This is definitely the situation in saturated formations where water fills the borehole and both depth of penetration of neutrons and source-receiver spacing are small. The effectiveness of soil-moisture meters may increase in unsaturated formations where the borehole is air filled. At least one group of experimenters (Flint and Flint, 1990) reported that the soil-moisture-meter approach, with short source-receiver spacings and thermal neutron measurements, can be an effective method for moisture logging in thick unsaturated zones.

The application of conventional neutron-porosity techniques in unsaturated formations has not been investigated in detail. For this reason, an investigation of the effect of source-receiver spacing was undertaken in an effort to understand the conditions under which the conventional neutron-porosity-logging technique might be applied to largediameter boreholes in unsaturated formations. The distribution of neutrons in a formation adjacent to a conventional neutron-logging device is illustrated in figure 19. The neutron population is described as a roughly spherical cloud of neutrons scattered and eventually absorbed by the formation. Conventional neutron logging is conducted such that the receiver 
is located on the outer edge of this spherical distribution. This optimum spacing is determined by seeking a source-receiver spacing large enough that the receiver is located on the outer edge of the cloud and yet is close enough to the center of the cloud to maintain useful counting rates. The position on the outer edge of the cloud is determined so that an asymptotic dependence of neutron counts on slowing-down length applies (Hearst and Nelson, 1985):

$$
q=\underline{k} \exp (-\underline{r} / \underline{L})
$$

where $g$ is the measured neutron flux at distance $\underline{r}$ from the source, $\underline{L}$ is the slowing-down length, and the constant $\underline{k}$ is a function of source intensity

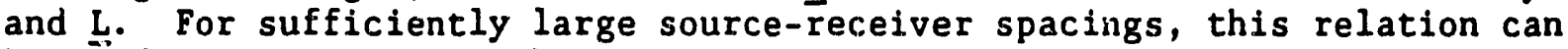
be used to estimate $L$ with conventional porosity probes.

The neutron-logging experiment described in this report was conducted as an empirical investigation of the neutron cloud generated adjacent to an air-filled borehole in an unsaturated formation containing relatively small amounts of water. The approach was to expand the conventional sourcereceiver spacing used in saturated formations in a series of steps up to more than twice the usual spacing associated with the far detector in a dual-detector logging probe. This expansion was expected to improve neutron-log performance for two reasons: (1) the large spacing would measure neutron fluxes in the appropriate far-field position for a much enlarged neutron cloud in unsaturated formations, and (2) the large spacing would be associated with a much larger volume of investigation and therefore might be a more representative sample of the unsaturated basalt and sediment environment.

The experiment was conducted using a typical dual-detector, slimhole neutron-logging probe with uncoated He detectors to measure epithermal and thermal neutrons. The measurements at increased source-receiver spacings were conducted by using a series of tool extensions designed for the purpose (table 3 ). The 20-inch extension was created by combining the 8- and 12-inch extensions. However, a slight incompatibility of threading on the connectors resulted in the inability to separate the two after the 8- and 20-inch-extension runs were completed. Therefore, no data were obtained for the 12-inch spacing. With this limitation, the data still include runs with three different spacers, producing responses from the two detectors at six different source-receiver spacings. Two repeat runs at each of the three spacings were made in well 45 . These provided a check to confirm that all logs were related to formation properties and were not an artifact of nuclear statistics.

The data obtained at the six different source-receiver spacings listed in table 3 reveal rather clearly that more than doubling the source-receiver spacing just begins to place the far detector toward the outer edge of the neutron cloud (fig. 19). The data indicate that measured neutron counts remain roughly constant or increase slightly for increasing source-receiver spacing over most of the separations. Only for the largest spacing does the measured count rate begin to decrease with increasing spacing. These results demonstrate that a source-receiver spacing of $4 \mathrm{ft}$ or more might be required for the operation of the conventional porosity probe as designed. Count rates at these large separations would be very low, making neutron 
Table 3.--Neutron source-receiver spacing (inches) in the dual-detector, variable spacing experiment

\begin{tabular}{lcccc}
\hline Connector/spacer & 0 inch & 8 inch & 12 inch & 20 inch \\
\hline $\begin{array}{l}\text { Near detector } \\
\text { separation (feet) }\end{array}$ & 0.75 & 1.4 & $1.7^{(1)}$ & 2.4 \\
Far detector & & & & \\
separation (feet) & 1.6 & 2.3 & $2.6^{(1)}$ & 3.3 \\
\hline
\end{tabular}

1 Data not obtained because of equipment failure 


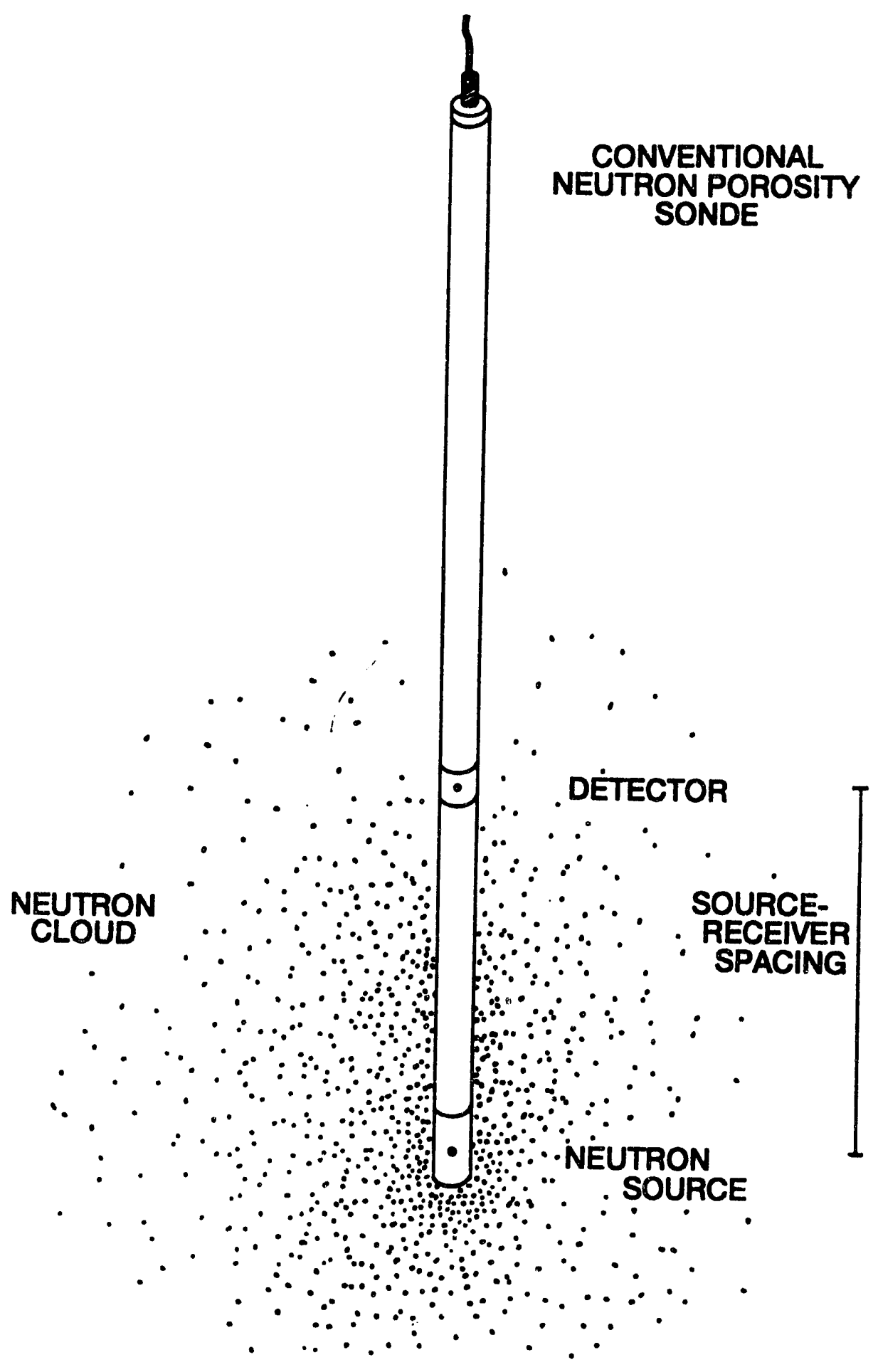

Figure 19. Schematic illustration of neutron cloud generated by neutron source in a conventional logging probe (from Keys, 1990). 
logging in the conventional mode quite difficult. However, the use of very large separations might still be useful, especially if very large sample volumes are of interest in aquifer characterization (as may be appropriate in layered basalts). This approach would clearly not be effective in defining relatively narrow saturation fronts. If such a spacing experiment were attempted, it would need to be conducted using either very slow logging speeds to ensure adequate nuclear statistics, or a stronger neutron source, or both.

Comparison of the neutron logs obtained in the unsaturated zone indicates that all six source-receiver spacings produce logs with approximately the same character, and all appear to be performing as neutron-moisture meters. This is inferred from the consistency of the character of the $\log$ as spacing is increased (fig. 20). That is, the data obtained at the larger spacings correspond to those obtained at the shortest spacing, where the $\log$ is most likely responding in the moisture-meter mode. This is also indicated by the correlation at several intervals between large count rates on the neutron logs and similarly large count rates on the natural-gamma log (fig. 21). The large gamma counts are probably associated with clay-mineral concentrations, which are likely to contain some bound water. Therefore, the increases in measured counts associated with the clay-rich horizons indicate that the response of the dual-detector neutron probe is proportional to water content and inversely proportional to neutron slowing-down length, $\underline{L}$. Other anomalously large neutron counts are associated with depth intervals not corresponding to gamma anomalies. Specifically, these appear at depths of $200 \mathrm{ft}$ and $360 \mathrm{ft}$ in figure 21 and could represent local variations in saturation or perched water zones not related to the clay-mineral distribution indicated by the gamma logs.

The results of the multiple source-receiver spacing experiment are not very encouraging for conventional neutron-porosity logging in unsaturated formations. The results depicted in figure 20 indicate that very large spacings greater than several feet would be needed in order to use the conventional porosity-calibration approach. Correspondingly, this tool configuration would be associated with large volumes of investigation and low counting rates: These results also indicate that the moisture-meter approach used by Flint and Flint (1990) is an effective means for characterizing the moisture content of the unsaturated zone and is not very sensitive to the particular source-receiver spacing used in the measurement.

\section{SURRARY}

A comprehensive geophysical logging program was undertaken in three wells near the Idaho Chemical Processing Plant in an effort to vertically profile changes in the local hydrogeology of the Snake River Plain aquifer at this site. The nuclear logs are characterized by the periodic appearance of high-porosity/low-density spikes that coincide with intervals of rubble or fractured and weak rock as determined from the televiewer and caliper logs. The neutron-porosity logs from wells 44,45 , and 46 illustrate the complexity of basalt-flow layering that underlies the INEL, where significant differences in the thickness and distribution of individual basalt flows are recognized in wells only a few hundred feet apart. The vertical distribution and orientation of fractures intersecting these wells also vary considerably. 


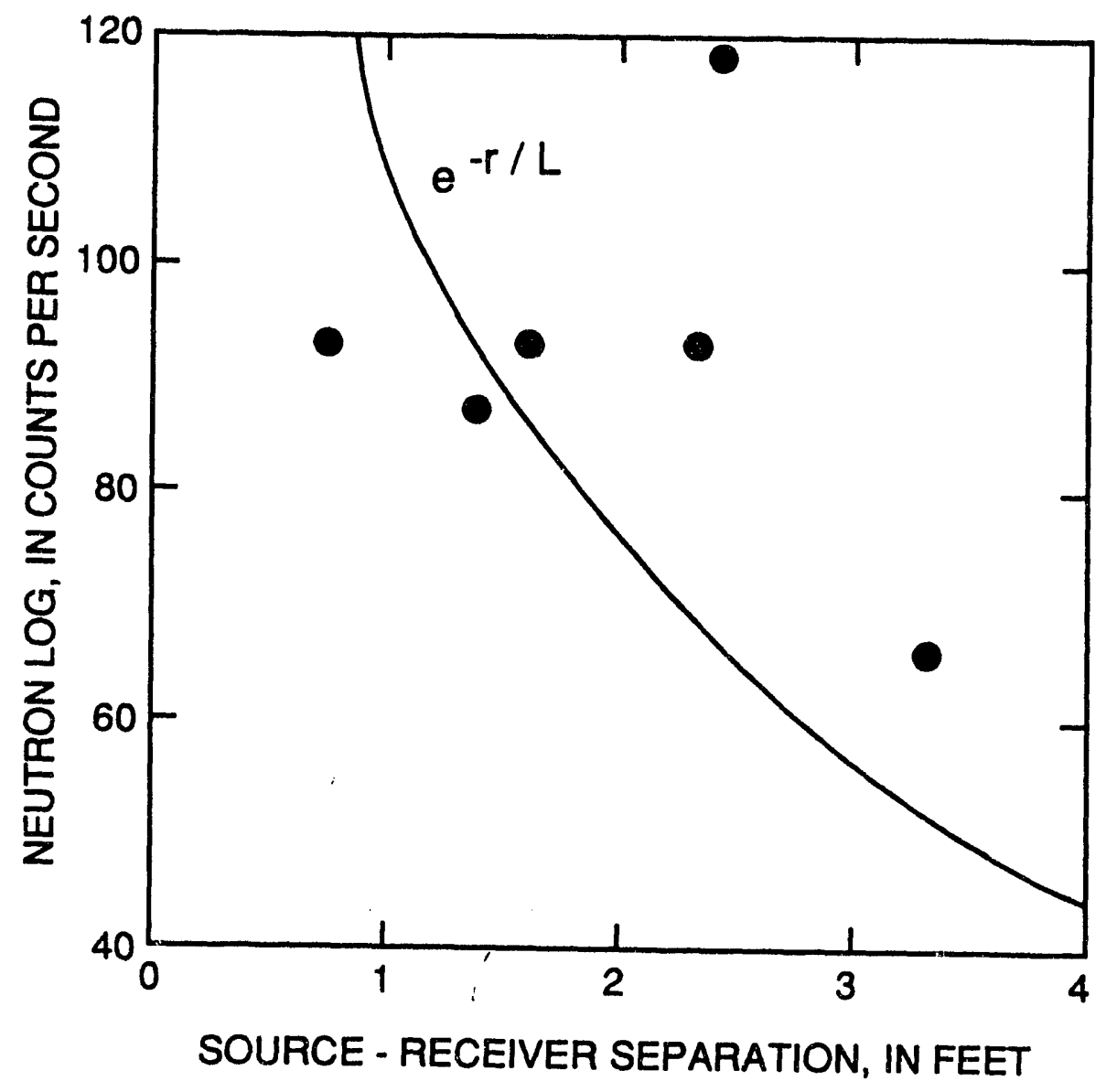

Figure 20. Graph showing neutron counts measured at six different sourcereceiver spacings in well 45 over a depth interval where count readings are nearly constant. Curve represents the neutron counts predicted by far-field scattering theory (refer to equation 3 in text). 

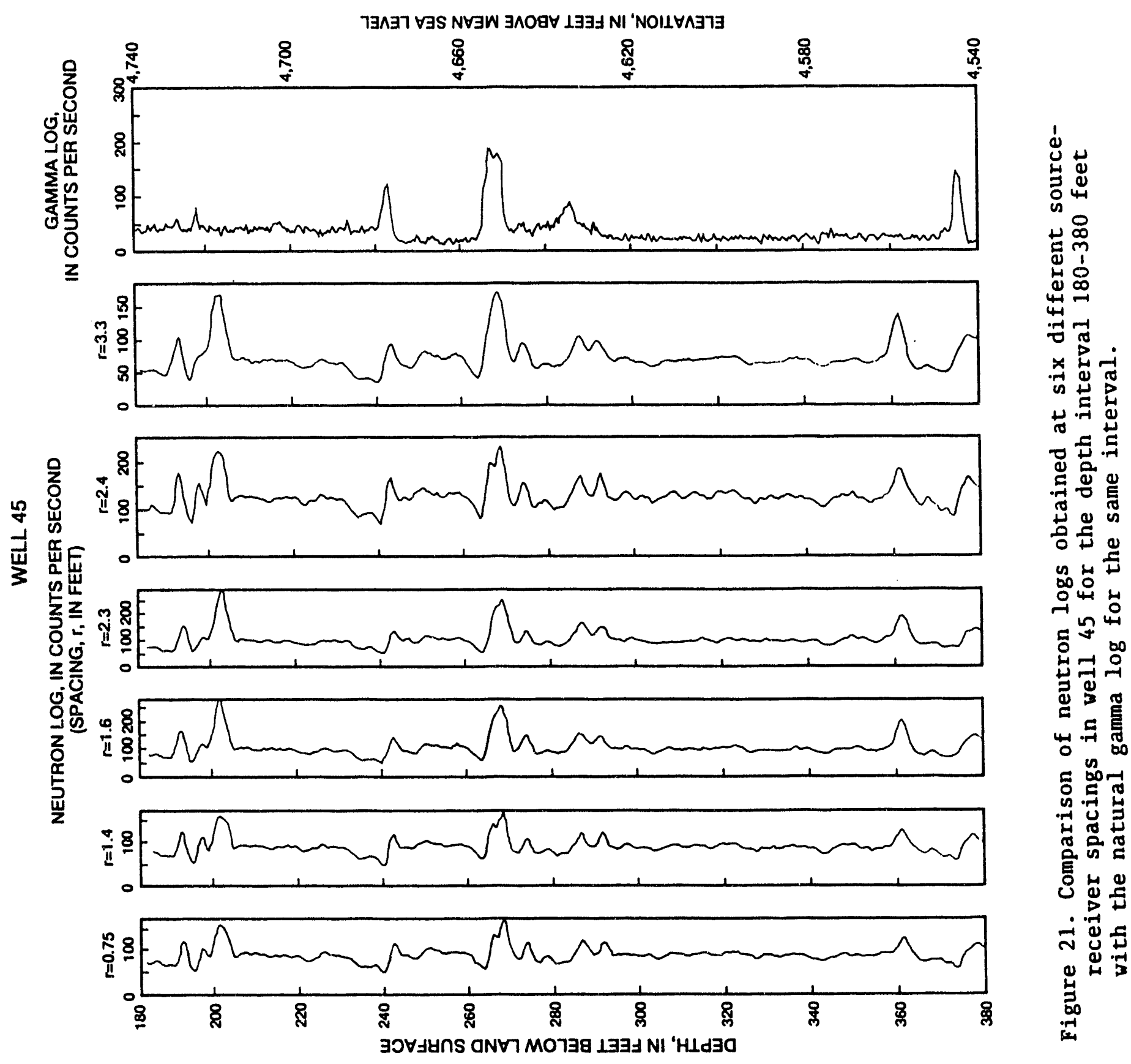
Aquifer heterogeneity is evident from the hydraulic measurements conducted during this investigation. The fluid-circulation patterns in wells 45 and 46 under ambient hydraulic head conditions are qualitatively similar and may indicate some degree of hydraulic communication between each other and with the supply wells at the ICPP. However, the flow pattern under ambient conditions for adjacent well 44 is substantially different. The hydraulic conductivity profiles presented in figure 12 demonstrate the large vertical variations within an individual well. Moreover, sizable variations in distributions and magnitudes of hydraulic conductivity exist in wells only $500 \mathrm{ft}$ apart. These hydrologic results underscore the wide range of transmissivity values spanning more than 6 orders of magnitude reported by Ackerman (1991) for 94 wells on or near the INEL. Also, reversal of in-hole flow with pumping at the ICPP supply well CPP2 indicates hydraulic communication with well 46 over approximately half a mile.

Thirteen in-situ gamma spectra were obtained in wells 44,45 , and 46 . The depths at which these were recorded coincided with the appearance of anomalously high energy peaks in the natural gamma logs. Subsequent spectral analyses reveal that the majority of the high gamma radiation is contributed by ${ }^{40} \mathrm{~K}$, a natural source of radioactivity with an easily distinguishable energy signature. The one notable exception occurs at the shallow depth of $32 \mathrm{ft}$ in well 45, where the sum of total collected counts is about twice that of any other spectrum (table 2), and the presence of $137 \mathrm{Cs}$ is detected in the unsaturated formation.

Repeat neutron logs in the unsaturated zone indicate that more than doubling the standard source-receiver spacings in conventional neutronporosity-logging probes does not result in data that can be calibrated in terms of saturated formation porosity. Rather, a source-receiver separation of $4 \mathrm{ft}$ or more is needed to approach this capability. Logging at such a large spacing would affect nuclear counting statistics and would encompass a very large sample volume. However, this configuration might be of interest in situations where effective sampling of large representative volumes is important. The results of the multiple source-receiver spacing experiment also indicate that the conventional neutron-porosity probe used in this study operates as a soil-moisture meter in the unsaturated zone of well 45 . The measured neutron counts increase slowly with increasing moisture content at all but the largest source-receiver separations and correlate with independer .udications of adsorbed water associated with clays as inferred from the nucural gamma log.

The results and interpretations presented in this report advance the understanding of the hydrostratigraphic regime underlying the INEL. The geophysical logs also supplement and extend the hydrogeologic data base for this area. The wide range of information generated from this investigation demonstrates the scientific value of borehole geophysics in the characterization of basalt aquifers and indicates a need for similar efforts in other wells at the INEL. 


\section{REFERENCES}

Ackerman, D.J., 1991, Transmissivity of the Snake River Plain aquifer at the Idaho National Engineering Laboratory, Idaho: U.S. Geological Survey Water-Resources Investigations Report 91-4058, 35 p.

Anderson, S.R., 1991, Stratigraphy of the unsaturated zone and uppermost part of the Snake River Plain aquifer at the Idaho Chemical Processing Plant and Test Reactors Area, Idaho National Engineering Laboratory, Idaho: U.S. Geological Survey Water-Resources Investigations Report $91-4010,71 \mathrm{p}$.

Barraclough, J.T., Teasdale, W.E., and Jensen, R.G., 1965, hydrology of the National Reactor Testing Station, Idaho: U.S. Geological Survey Report (IDO-22048), $122 \mathrm{p}$.

Barraclough, J.T., Robertson, J.B., and Janzer, V.J., 1979, Geohydrologic study of a burial site for solid low-level radioactive wastes at the Idaho National Engineering Laboratory--Management of low-level radioactive waste, vol. 2, M.W. Carter, A.A. Moghissi, and B.R. Kahn, eds.: New York, Pergamon Press, p. 795-824.

Barrash, Warren, and Morin, R.H., 1987, Hydrostratigraphy and distribution of secondary permeability in the Brule Formation, Cheyenne County, Nebraska: Geological Society of America Bulletin, v. 99, p. 445-462.

Cooper, H.H., and Jacob, C.E., 1946, A generalized graphical method for evaluating formation constants and summarizing well-field history: Transactions, American Geophysical Union, v. 27, no. 4, p. 526-534.

Flint, L.E., and Flint, A.L., 1990, Preliminary permeability and waterretention data for nonwelded and bedded tuff samples, Yucca Mountain area, Nye County, Nevada: U.S. Geological Survey Open-File Report $90-569,57 \mathrm{p}$.

Garabedian, S.P., 1989, Hydrology and digital simulation of the regional aquifer system, eastern Snake River Plain, Idaho: U.S. Geological Survey Open-File Report 87-237, 151 p.

Hearst, J.R., and Nelson, P.H., 1985, Well logging for physical properties: New York, McGraw-Hill, 571 p.

Hess, A.E., 1986, Identifying hydraulically conductive fractures with a slow-velocity borehole flowmeter: Canadian Geotechnical Journal, $\nabla$. 23, no. 1, p. 69-78.

Hess, A.E., and Paillet, F.L., 1990, Applications of the thermal-pulse flowmeter in the hydraulic characterization of fractured rocks-Proceedings, Geophysical Applications for Geotechnical Investigations: Philadelphia, Pa., American Society for Testing and Materials ASTM STP 1101 , p. $99-112$. 
Hess, K.M., 1989, Use of a borehole flowmeter to determine spatial heterogeneity of hydraulic conductivity and macrodispersion in a sand and gravel aquifer, Cape Cod, Massachusetts; in F.J. Molz and others, eds., Proceedings of the Conference on New field techniques for quantifying the physical and chemical properties of heterogeneous aquifers: Dublin, Ohio, National Water Well Association, p. 497-508.

Hufschmied, P., 1984, Hydrogeologic emmental, teil IV, modellstudie zur bestimmung des grundwasserdargebotes im testgebiet emmental: Wasser-u, Energiewirtschaftsamt des Kantons Bern, 300 p.

Jones, P.H., 1961, Hydrology of waste disposal, National Reactor Testing Station, Idaho--an interim report: U.S. Geological Survey Report (IDO-22042), $152 \mathrm{p}$.

Keys, W.S., Eggers, D.E., and Taylor, T.A., 1979, Borehole geophysics as applied to the management of radioactive waste--site selection and monitoring: Management of low-level radioactive waste, vol. 2, M.W. Carter, A.A. Moghissi, and B.R. Kahn, eds.: New York, Pergamon Press, p. 955-982.

Keys, W.S., 1990, Borehole geophysics applied to ground-water investigations: U.S. Geological Survey Techniques of Water-Resources Investigations, book 2, chap. E2, $150 \mathrm{p}$.

Mann, L.J., 1986, Hydraulic properties of rock units and chemical quality of water for INEL-1a; 10,365-foot-deep test hole drilled at the Idaho National Engineering Laboratory, Idaho: U.S. Geological Survey WaterResources Investigations Report 86-4020, 23 p.

Molz, F.J., Morin, R.H., Hess, A.E., Melville, J.G., and Guven, Oktay, 1989, The impeller meter for measuring aquifer permeability variations: evaluation and comparison with other tests: Water Resources Research, v. 25 , no. 7 , p. 1677-1683.

Horin, R.H., 1988, Determining the vertical distribution of hydraulic conductivity in-situ by concurrent injection and geophysical logging: Proceedings, International Conference on Fluid Flow in Fractured Rocks, Atlanta, May 15-18, Georgia State University, p. 346-354.

Morin, R.H., Hess, A.E., and Paillet, F.L., 1988, Determining the distribution of hydraulic conductivity in a fractured limestone aquifer by simultaneous injection and geophysical logging: Ground Water, $\nabla$. 26 , no. 5, p. 587-595.

Morin, R.H., Moos, Daniel, and Hess, A.E., 1992, Analysis of the borehole televiewer log from DSDP Hole 395A--results from the DIANAUT program: Geophysical Research Letters, $\nabla .19$, no. 5, p. 501-504.

Morris, D.A., Hogenson, G.M., Teasdale, W.E., and Shuter, E.A., 1963, Hydrology of waste disposal, National Reactor Testing Station, Idaho, annual progress report--1962: U.S. Geological Survey Report (IDO-22044), $99 \mathrm{p}$. 
Paillet, F.L., 1991, Graphical overlay applications in geotechnical log analysis, Proceedings, Fourth International Minerals and Geotechnical Logging Society/Canadian Exploration Geophysical Society Symposium on Borehole Geophysics for Minerals, Geotechnical and Groundwater Applications: Toronto, Canada, Minerals and Geotechnical Logging Society, p. 43-59.

Palllet, F.L., and Kim, Kunsoo, 1987, Character and distribution of borehole breakouts and their relationship to in situ stresses in deep Columbia River basalts: Journal of Geophysical Research, v. 92, no. B7, p. 6223-6234.

Paillet, F.L., Hess, A.E., Cheng, C.H, and Hardin, E.N, 1987, Characterization of fracture permeability with high-resolution vertical flow measurements during borehole pumping: Ground Water, v. 25, no. 1 , p. $28-40$.

Pittman, J.R., Jensen, R.G., and Fischer, P.R., 1988, Hydrologic conditions at the Idaho National Engineering Laboratory, 1982 to 1985: U.S. Geological Survey Water-Resources Investigations Report 89-4008 (IDO-22078), 73 p.

Rehfeldt, K.R., Hufschmied, Peter, Gelhar, L.W., and Schaefer, M.E., 1988, The borehole flowmeter technique for measuring hydraulic conductivity variability: Electric Power Research Institute, Topical Report EPRI EA-2485-5, Palo Alto, Calif., 244 p.

Robertson, J.B., Schoen, R.N.', and Barraclough, J.T., 1974, The influence of liquid waste disposal on the geochemistry of water at the National Reactor Testing Station, Idaho--1952-70: U.S. Geological Survey Open-File Report (ID0-22053), 231 p.

Schimschal, Ulrich, 1980, Quantitative effects of lithology, borehole environment, and probe design in gamma spectral logging with scintillation crystals: Log Analyst, v. 21 , no. 5, p. 3-10.

White, F.M., 1979, Fluid mechanics: New York, McGraw-Hill, 701 p.

U.S. Department of Energy, 1990, Comprehensive well survey for the Idaho National Engineering Laboratory: U.S. Department of Energy, Idaho Falls, Idaho, 144 p.

Zemanek, J., Glenn, E.E., Norton, L.J., and Caldwell, R.L., 1970, Formation evaluation by inspection with the borehole televiewer: Geophysics, $\nabla$. 35, p. 254-269. 
DATE

FILMED

$8 / 12 / 93$ 
